Universidade de Brasília

Centro de Excelência em Turismo

Especialização Em Qualidade Em Alimentos

\title{
PERFIL HIGIÊNICO-SANITÁRIO DE FEIRAS-LIVRES DO DISTRITO FEDERAL E AVALIAÇÃO DA SATISFAÇÃO DE SEUS USUÁRIOS.
}

DANIEL MARCHIORI SILVA RODRIGUES

Monografia apresentada ao Centro de Excelência em Turismo da Universidade de Brasília como requisito parcial para a obtenção do certificado de Especialista em Qualidade em Alimentos.

Orientação: Profa. RAQUEL BOTELHO

Brasília, DF, junho de 2004 
UNIVERSIDADE DE BRASÍLIA

Centro de Excelência em Turismo

Curso de Especialização em Qualidade em Alimentos

PERFIL HIGIÊNICO-SANITÁRIO DE FEIRAS-LIVRES DO DISTRITO FEDERAL E AVALIAÇÃO DA SATISFAÇÃO DE SEUS USUÁRIOS.

DANIEL MARCHIORI SILVA RODRIGUES

\author{
Banca Examinadora
}

Prof. (a) RAQUEL ASSUNÇÃO BOTELHO Orientadora

Prof. (a) WILMA COELHO ARAÚJO

Membro da Banca

Brasília, DF, 15 de Junho de 2004 


\section{Ficha Catalográfica}

Marchiori, Daniel Silva Rodrigues

Perfil higiênico-sanitário de feiras-livres do

Distrito Federal e avaliação da satisfação de seus usuários / Daniel Marchiori Silva Rodrigues 2004.

Viii, 64 pág.; 5 il.

Monografia (especialização) - Universidade de Brasília, Centro de Excelência em Turismo, 2004.

Orientação: Prof.a Raquel Assunção Botelho.

1. Feira 2. Satisfação 3. Higiene.

I. Título. 
DANIEL MARCHIORI

PERFIL HIGIÊNICO-SANITÁRIO DE FEIRAS-LIVRES DO DISTRITO FEDERAL E AVALIAÇÃO DA SATISFAÇÃO DE SEUS USUÁRIOS.

COMISSÃO AVALIADORA

PROFESSOR(a) RAQUEL ASSUNÇÃO BOTELHO

PROFESSOR(a) WILMA COELHO ARAÚJO

PROF. Y

Brasília, DF, 15 de Junho de 2004. 


\section{DEDICATÓRIA}

A "Nossa senhora minha protetora e iluminadora". A mim, Daniel Marchiori, por ser paciente e dedicado.

A minha mãe, a quem devo tudo, especialmente a vida. 


\section{AGRADECIMENTOS}

À Profa. Raquel Botelho, minha orientadora, exemplo de competência profissional, por me aceitar como aluno, acima de tudo, por ser uma pessoa encantadora!

Aos amigos do curso de Especialização em Qualidade em Alimentos, especialmente a Karina, Lilian, Andrea, Denise, Milena, Thais, Vanessa, Tatiana e Roger, Roberto e Adimilsom entre outros.

À Margarida Leite professora da Faculdade de Ciências Exatas, Administrativas e Socias (Faceas) da União Pioneira de Integração Social - UPIS pela colaboração e incentivo, bem como a todos os professores do curso de especialização do Centro de Excelência em Turismo da Universidade de Brasília.

Aos amigos Gustavo, Sérgio, pela amizade e apoio nos momentos difíceis.

Aos amigos Ricardo, Alfredo, Bernardo Saião, Túlio, Yberê, Zeno e Alessandro pelos vários momentos divertidos...

Aos meus amigos e colegas pela compreensão nos momentos em que não pude estar presente, mas obrigado por sempre pensarem que existo.

Aos funcionários do CET pelas gentilezas, atenção e dedicação, especialmente a Maria das Graças Faria, Joaquim Pedro de Oliveira Júnior.

A meus irmãos Samantha e Luiz Augusto Marchiori, por me ajudar com as atividades no computador e impressão.

A minha namorada Michelle Gonçalves Alcantara, pelo carinho que nos une, apoio, compreensão e companheirismo.

Aos meus familiares, pelo incentivo e apoio dos momentos difíceis, especialmente aos meus Pais, Luiz Gonzaga e Sandra Marchiori.

Agradeço, finalmente, a todas as pessoas que direta ou indiretamente colaboraram nesta trajetória... 
"As doenças atacam as pessoas não como um raio em céu azul, mas são conseqüências de contínuos erros contra a natureza".

Hipócrates 
Páginas.

RESUMO.

01

ABSTRACT.

LISTA de ABREVIATURAS.

LISTA de QUADROS.

04

LISTA de FIGURAS. 05

LISTA de ANEXOS. 06

1. INTRODUÇÃO.

2. OBJETIVOS. 09

3. REVISÃO BIBLIOGRÁFICA. 10

3.1 Histórico (Europa, São Paulo e Rio de Janeiro). 10

3.2 Qualidade e Risco nas Feiras. 15

4. METODOLOGIA. 21

5. RESULTADOS E DISCUSSÃO. 22

5.1 Clientela Atendida. $\quad 22$

5.2 Perfil higiênico-sanitário das feiras-livres do DF. 25

5.3 Higiene das bancas (utensílios, equipamentos)

5.4 Características da infra-estrutura

(instalações, bancas, vias de acesso) das feiras. 28

6. CONCLUSÃO. 30

7. REFERÊNCIAS BIBLIOGRÁFICAS. 32

8. ANEXOS. 35

Anexo 1. (Portaria SVS/MS n'26/97) 36

Anexo 2. (Pesquisa de satisfação) 39

Anexo 3. (RDC n²75/2002) 40 


\section{RESUMO}

A necessidade de avaliar a condição da qualidade de locais como feiras, na qual se comercializam alimentos, considerando entre outros aspectos, o risco constante de contaminação alimentar foi um dos aspectos relevantes para a realização deste trabalho. Neste contexto objetivou-se descrever o perfil da qualidade higiênico-sanitária e de satisfação em feiras no Distrito Federal. Para identificar os riscos, utilizou-se a lista de verificação de boas praticas de fabricação (Brasil, 2002) e para avaliar a satisfação dos usuários das feiras, utilizou-se um questionário com perguntas fechadas (anexo 2). As análises dos dados e as observações efetuadas possibilitaram constatar que $90 \%$ dos estabelecimentos apresentaram-se insatisfatório para exercerem as atividades neste ramo. Os maiores índices de inadequações referem-se às condições físicas; produção e transporte (armazenamento e exposição), aos manipuladores; higiene pessoal (feirantes) e edificações e instalações; precária higiene e estado de conservação.

Palavras-chave: feira - livre, satisfação, higiene 


\section{ABSTRACT}

The objective of this study was to describe the hygiene quality profile and satisfaction in fairs of Distrito Federal. The risks were identified through the satisfaction research and Anvisa's check list RDC n²75 (Brasil, 2002). The idea was to demonstrate the need to have quality control in fairs in all of the processes related to them. It is observed the importance of all professionals' involvement in the food chain, especially producers, fair workers, helpers and the local administration, not excluding the population and the government. The results and data analysis show that $90 \%$ of the establishments are unsatisfactory to conduct their activities in this field. The greater rates of inadequacy are related to physical conditions, production and transport, workers, personal hygiene and installations. Considering these results, it is necessary the improvement and establishment of control strategies in order to go through all the steps related to the food chain.

Key words: fair, satisfaction, hygiene 


\section{LISTA DE ABREVIATURAS}

ANVISA - Agência Nacional de Vigilância Sanitária

CEAGESP - Central de Abastecimento Geral do Estado de São Paulo

DOU - Diário Oficial da União

DOM - Diário Oficial Municipal

DF - Distrito Federal

DVAs - Doenças veiculadas a alimentos

MAPA - Ministério da Agricultura, Pecuária e Abastecimento

MS - Ministério da Saúde

RDC - Resolução da Diretoria Colegiada

SEC - Século

SVS - Secretaria de Vigilância Sanitária 


\section{LISTA DE QUADROS}

Página.

Quadro 1. Classificação das feiras conforme roteiro observacional (lista de verificação). 


\section{LISTA DE FIGURAS}

Página.

Figura 1. Caracterização dos feirantes higiene pessoal.

Figura 2. Características da infra-estrutura(bancas, instalações, vias de acesso).

Figura 3. Organização, higiene das feiras. Opinião dos usuários.

Figura 4. Higiene das bancas (utensílios, equipamentos) aquisição e armazenamento dos alimentos 


\section{LISTA DE ANEXOS}

Página.

Anexo 1. Portaria SVS/MS n²6, de 08 de julho de 1997.

Anexo 2. Pesquisa de satisfação (questionário).

39

Anexo 3. RDC $n^{\circ} 275$, (Roteiro Observacional lista de verificação ANVISA).

40 


\section{INTRODUÇÃO}

Em tempos marcados por ofertas tentadoras de supermercados e fast food em qualquer lugar e esquina, ainda é a tradicional feira que mobiliza moradores dos bairros e de cidades satélites entre outros logradouros onde são localizadas. $\mathrm{O}$ consumidor que freqüenta a feira encontra variedade, bom preço e atendimento personalizado, isto sem contar o próprio conforto de estar perto de casa.

Em muitas regiões do país as feiras são organizadas, registradas e fiscalizadas pela administração local para certificar a higiene e a qualidade dos produtos comercializados diariamente. Por outro lado acredita-se que é possível inovar uma forma de comercialização, ampliando as oportunidades de mercado para os produtos da agricultura, pecuária e artesanatos em geral, criando marcas locais e viabilizando pequenas agroindústrias, a produção de produtos orgânicos e livres de agrotóxicos.

A feira designa a comercialização de alimentos para o consumo humano, e que são vendidos nas ruas ou lugares públicos previamente determinados pela administração local. Os usuários das feiras costumam encontrar um ambiente amistoso por parte dos feirantes, que auxiliam na compra dos alimentos, além de ensinarem receitas e formas de conservação e uso dos alimentos.

Acredita-se que no Distrito Federal as feiras livres ou permanentes atendem variavelmente as necessidades das populações entre baixa, média e alta renda, promovendo por sua vez o resgate da cultura e das tradições populares, além de contribuírem para o fortalecimento da atividade mercantil, na medida em que favorecem a integração entre membros da comunidade.

Embora este tipo de comércio esteja vivendo época de rápidas transformações, tanto tecnológicas como comerciais, a qualidade é um componente vital para a sustentação no mercado e um quesito para assegurar o emprego, bem como para a saúde do ser humano e primordial no que diz respeito à segurança alimentar.

A oferta e a comercialização de alimentos por feirantes e ambulantes podem trazer conseqüências indesejáveis ao consumidor. A feira é considerada potencial veiculador quanto à ocorrência de doenças de origem alimentar e representa 
atualmente um dos desafios aos serviços de vigilância-sanitária, uma vez que proliferam a cada momento e não há grande preocupação do governo para fiscalizálos adequadamente.

Contudo, mais do que um local de comercialização e da divulgação de produtos locais e do entorno do Distrito Federal, as feiras são ponto de encontro da comunidade, atraída pelo bate-papo e pela oportunidade de fazer novas amizades com os moradores dos locais vizinhos que visitam a feira. Além disso, outros aspectos importantes, a expectativa por obter produtos higiênicos, com boa aparência e preço adequado e identificação estimulam também a ida dos usuários.

As feiras também desempenham um papel sócio-econômico fundamental. O produtor rural, de agricultura familiar, pode dispor de espaço fixo para comercializar a produção da propriedade ou da granja, e sente mais seguro para sustentar a família. Socialmente, isto significa a fixação do homem do campo; o combate ao êxodo rural, o aumento de empregos formais e informais, e possibilidades naturais de sobrevivência.

O que freqüentemente se aborda é a necessidade de fortalecer as organizações sócio-econômicas da categoria para ressaltar sua importância ao desenvolvimento do país. Nesse sentido, para o acesso ou para consolidação nos mercados, também se faz necessário criar alternativas para concretizá-los. Assim, iniciativas nos diversos campos podem ser promovidas, desde o fortalecimento de estratégias locais até no comércio internacional, exigindo esforços da sociedade civil e do governo. As feiras podem representar a possibilidade de fortalecer a agricultura familiar principalmente, no âmbito local e regional, e na difusão de agronegócios entre outros fatores.

Nesse contexto, entende-se que o público consumidor e os feirantes na maioria produtores devem estar cada vez mais esclarecidos quanto as suas responsabilidades na preservação da saúde da coletividade. 


\section{OBJETIVOS}

\section{Geral:}

O presente estudo tem como objetivo avaliar e identificar o perfil higiênicosanitário das feiras - livres no DF e avaliação da satisfação de seus usuários.

\section{Específicos:}

Descrever os fatores que interferem na aceitabilidade da comercialização de produtos nestas feiras;

Descrever o perfil higiênico-sanitário das feiras - livres;

Definir o perfil das pessoas que freqüentam as feiras

Avaliar a satisfação de seus usuários; 


\section{REVISÃO BIBLIOGRÁFICA}

Feira do latim, feria (dia de festa), local onde se faz mercado, grande mercado livre realizado em épocas, dias fixos. Lugar onde há inserção quase total de impostos (Barsa, 1991). Lugar público onde se expõem e vendem mercadorias, onde há reunião de produtores e consumidores, em caracter periódico e temporário para a comercialização de produtos característicos da região (Luft, 1984).

Existem dois tipos de feira: a livre e a permanente. A primeira entende-se por atividade mercantil de caracter cíclico, realizada em local público previamente designado pela administração local, com instalações provisórias e removíveis, que pode ocorrer em vias, logradouros públicos ou ainda em área pública coberta, do tipo pavilhão (Brasil, 1998).

A feira permanente é uma atividade mercantil de caráter constante, realizada em área pública previamente designada pela administração local, com instalações comerciais fixas e edificadas para a comercialização de produtos diversos (Brasil, 1998).

As feiras têm como objetivo comum proporcionar o abastecimento suplementar de produtos hortifrutigrangeiros, cereais, doces, carnes, pescados, laticínios, flores e artesanatos, etc. Além de viabilizar o aumento do consumo interno de alimentos e geração de saldos maiores na balança comercial dos produtos agrícolas e seus derivados; ampliar as oportunidades de inclusão econômica e social para a expressiva parcela de brasileiros, por meio de mecanismos de integração ao mercado e geração de produção e emprego; fortalecer o caráter estruturante da agricultura familiar como atividade importante para a irradiação do crescimento aos demais setores da economia e para a interiorização do desenvolvimento nacional (Brasil, 2003).

\subsection{HISTÓRICO}

\section{Europa}

As feiras existiam já na antigüidade (Delfos, Delos) e na alta Idade Média (feira de Saint-Denis ou do Lendit, sec XV). Seu verdadeiro progresso correspondeu, contudo, à renovação comercial na Europa medieval, onde era o órgão essencial da 
vida econômica internacional. Favorecidos pelos senhores e pelos reis que concediam privilégios a seus participantes (garantia de herança, garantia contra prisão por dívidas, autorização de empréstimos a juros), funcionavam também como bolsas de valores que aceitavam letras de câmbio e pagamento a termo.

Desenvolveram-se nas cidades situadas ao longo dos grandes corredores comerciais, nas encruzilhadas das estradas que iam da Itália aos Países Baixos e das cidades da Hansa à lle de France. As feiras da Champagne eram as mais importantes nos séculos XII e XIII. Próximas ao Mediterrâneo, as feiras de Languedoc (Numes Carcassone, Saint Gilles) viram sua importância crescer por obra do renascimento comercial do sec XII e do recuo do Islã. A importância das feiras declinou a partir do sec XIV, com a? das companhias comerciais, a maior parte desapareceu após o sec XVII (Barsa, 1990).

Nos primórdios da sociedade feudal, a aldeia era praticamente auto-suficiente; a vida econômica decorria sem muita utilização de capital. Era uma economia de consumo. O servo e sua família cultivavam seu alimento, fabricavam com as próprias mãos tudo o que lhes era necessário. Os servos que demonstravam habilidades de confecção eram atraídos à casa do senhor, a fim de fazer os objetos de que aqueles precisavam.

Naquele período, a palavra "mercado livre" denominava o local, o espaço físico, onde, semanalmente, realizava-se a troca de produtos excedentes atualmente chamado feira. Pelos costumes da época, mulheres e crianças não iam ao mercado, pois lá era lugar em que se "enganavam pessoas". O comércio no mercado não era intenso, já que não havia incentivo à produção de excedentes. Fazia-se intercâmbio de produtos pela necessidade de consumo e não pela procura do produto. $\mathrm{O}$ mercado semanal era mantido junto ao mosteiro ou ao castelo. Os mercadores estavam sob o controle do senhor do feudo ou do bispo, que, também naquele local, faziam a transação de mercadorias, trocavam os excedentes produzidos por seus servos e artesãos (www.eps.ufsc.br/teses98/ester/cap2a.html).

A transformação veio através do enfraquecimento do feudalismo e foi impulsionada pela necessidade que a nobreza sentiu de ampliar suas fontes de recursos; pela necessidade do desenvolvimento do comércio e das cidades; pelo 
fortalecimento de novas relações de trabalho, baseadas no trabalho livre, assalariado; e pelo surgimento de novas camadas sociais, como a burguesia.

$\mathrm{Na}$ Europa ocidental, de modo geral, o sistema caminhou para a abertura, com mudança de relações servis para relações livres de trabalho. Na Europa oriental, ocorreu um fechamento do sistema, com a manutenção das relações servis, que se tornaram ainda mais rígidas.

O renascimento comercial e urbano, e o crescimento da população da Europa Ocidental, intensificaram a procura por alimentos e outros artigos de consumo. Os senhores começaram a produzir para vender e, para aumentar a produção, passaram a utilizar o trabalho temporário de feirantes (www.lasalle.g12.br/ensino/brito/cap31.htm,2004).

$\mathrm{Na}$ Baixa Idade Média, os nobres precisavam de dinheiro para comprar produtos nas feiras internacionais, no mercado oriental e nas feiras locais. Também necessitavam pagar a mão-de-obra contratada pelos serviços prestados. Os senhores feudais obtinham recursos vendendo na produção da terra e a liberdade dos servos, cobrando impostos, arrendando suas propriedades, emprestando dinheiro de companhias e explorando novos mercados.

Por meio da expansão marítima, a burguesia européia abriu novos mercados ao comércio internacional, capazes de fornecer alimentos, especiarias e metais a baixo custo e consumir os produtos artesanais e alimentos fabricados e produzidos na Europa (www.lasalle.g12.br/ensino/brito/cap31.htm,2004).

\section{Brasil: São Paulo}

O comércio de alimentos em feiras-livres é uma prática antiga no Brasil. As feiras funcionavam no município de São Paulo, desde meados do século XVII, haja vista a ocorrência de uma certa oficialização para a venda de gêneros da terra, como hortaliças e peixe em 1687.

No inicio do século XVIII, nota-se a distinção entre alguns ramos do comércio, aparecem as lojas ou vendas, onde se compravam fazendas (tecidos) e gêneros alimentícios semi-perecíveis e também as quitandas que ofereciam hortaliças e frutas. No final do século XVIII e começo do século XIX, estruturam-se as feiras fora 
da cidade, nos locais de pouso de tropas, para a comercialização de mercadorias e gêneros alimentícios.

Em 1914 foi criada a feira livre através do ato do prefeito Washington Luiz P. de Souza, não como um projeto novo, mas sim, como algo que já existia tradicionalmente na cidade de São Paulo.

A primeira feira livre oficial, realizada a titulo de experiência, contou com a presença de 26 feirantes e teve lugar no Largo General Osório, a segunda realizouse no Largo do Arouche, com a presença de 116 feirantes e que atualmente é a feira mais famosa de São Paulo mas com outra distinção chamada de mercado municipal (Ceagesp) e, a terceira foi efetuada no Largo Morais de Barros.

Em 1915, as feiras perfaziam o total de 7: sendo duas no Largo General Osório, duas no Largo do Arouche e as demais no Largo Morais de Barros, Largo São Paulo e na Rua São Domingos. A partir de então, sob nova prefeitura, o prefeito Antônio Carlos Assumpção, através do ato n. ${ }^{\circ} 628$, reorganizou as feiras livres e abriu a comercialização de produtos não alimentícios. Incutiu no feirante à ética profissional introduzindo nos trabalhos por eles efetuados noções de higiene (www.prodam.sp.gov.br/semab/mercados/feiras.htm).

Em 1948, há uma expansão considerável das feiras livres, pelo fato de que pelo menos uma feira semanal tinha que ser instalada em cada subdistrito ou bairro da cidade. Foi então a partir dessa determinação que o município de São Paulo, por ser o grande polo gerador de know-how para as demais regiões do país, regulamentou por sua funcionalidade em caráter supletivo o abastecimento e escoamento da produção de hortifrutigranjeiros além do tradicional comércio de pescados. Por outro lado as feiras eram vistas como fortes fontes de empregos e renda (www.prodam.sp.gov.br/semab/mercados/feiras.htm, 2004).

Somente na cidade de São Paulo há atualmente cerca de 867 feiras livres, que atendem aproximadamente 900 mil pessoas por mês, funcionando o ano inteiro. Frente a este elevado número, a prefeitura implantou o programa Qualidade Total nas feiras livres, objetivando monitorar as condições higiênico-sanitárias dos grupos de alimentos comercializados nas feiras livres (Quintaes \& Vargas, 2004). 


\section{Brasil: Rio de Janeiro}

As feiras livres constituem-se no Rio de Janeiro numa prática comercial tão antiga quanto a própria cidade. No Rio colonial era muito comum o comércio de gêneros alimentícios nas praças e ruas. Na região do porto, atual Praça XV, localizavam-se as barracas que vendiam pescados e outros gêneros que chegavam nos barcos para o abastecimento direto da cidade (www.rio.rj.gov.br/clf/feiras/historia.htm).

Tal comércio era feito informalmente, até que em 1771, o Marquês do Lavradio, terceiro vice-rei do Brasil, autorizou os mercados de alimentos nas ruas do Rio. Dessa forma, as barracas do adro da Igreja da Glória desceram para o Largo do mesmo nome, para assumir as características das feiras livres de hoje (www.rio.rj.gov.br/clf/feiras/historia.htm).

Das feiras coloniais que se situavam próximas ao mercado do peixe, no Largo do Paço, onde se encontrava a população e os produtores às feiras atuais, já se vão quatro séculos.

Apesar de serem uma prática tão antiga, somente tiveram o reconhecimento formal pela administração pública em 1904, quando no intuito de se exercer um maior controle sobre tal atividade para o reordenamento da cidade, o Prefeito Pereira Passos editou o Decreto n. ${ }^{9}$ 997, de 13 de outubro de 1904, que autorizava o funcionamento das referidas feiras aos sábados, domingos e feriados.

Em 1916, em decorrência do grave problema de abastecimento pelo qual passava a cidade como conseqüência da Primeira Guerra Mundial, foi expedido pelo Prefeito Azevedo Sodré, o Decreto no 1752 que autorizava o funcionamento de feiras ou mercados livres nos dias da semana previamente designados. Nessa época, as feiras livres assumiram um papel tão importante no abastecimento da cidade, que eram estimuladas e abastecidas pelo próprio governo, por meio do Fomento Agrícola.

Em 1933, os feirantes já se encontravam organizados em categorias e tinham inclusive um jornal de classe chamado "feirante" (www.rio.rj.gov.br/clf/feiras/historia.htm). 
Atualmente são 182 feiras livres espalhadas em toda a cidade, que diretamente empregam 6.000 feirantes devidamente licenciados, e garante a sobrevivência indireta de cerca de 30.000 pessoas. As feiras livres são atualmente regidas pela Lei n. ${ }^{\circ}$ 492/84., Ademais, as feiras ainda movimentam considerável volume de hortifrutigranjeiros e pescados na cidade.

É, portanto uma atividade com relevância econômica para a cidade, e de sobrevivência de milhares de pessoas que vivem do que ganham nas feiras livres. Porém, este tipo de atividade, tem causado além dos benefícios, muitos problemas relativos ao seu ordenamento, limpeza e controle. Nesse sentido, a atual Administração Municipal está desenvolvendo o projeto "Rio-Feiras", visando criar um novo padrão para este tipo de comércio na cidade. (www.rio.rj.gov.br/clf/feiras/historia.htm).

\subsection{QUALIDADE E RISCO NAS FEIRAS-LIVRES}

Todo o tipo de gênero alimentício destinado à comercialização deve satisfazer as exigências de qualidade do consumidor, possuindo adequada aparência, além de boas condições de higiene e sanidade. Quando o alimento não apresenta adequadas condições higiênico-sanitárias, pode causar doenças veiculadas por alimentos (DVAs) e consequentemente surtos de toxinfecções alimentares (AYRES, et al., 2003).

A garantia da qualidade dos alimentos representa hoje um anseio dos consumidores no mundo inteiro, relacionando alimentação adequada à saúde. Existem fatores desejáveis que determinam os parâmetros de qualidade necessários para a manutenção das feiras, mas não se pode admitir a comercialização de produtos que se constituem em riscos à população. $O$ valor agregados da qualidade aos alimentos decorre de alguns fatores inerentes ao alimento: alimentos livres de agrotóxicos, adequada consistência, que estejam em ambientes saudáveis livres de sujidades.

Como em qualquer outro negócio, a permanência de atividades mercantis no agronegócio de feira depende dentre outros fatores de um conjunto de vantagens, comparativas? que lhe assegurem seu lugar (Moretti, 2000). Dentre estas vantagens, acredita-se que a qualidade e a segurança alimentar do produto no que diz respeito à 
inexistência de contaminação de origem química, física ou microbiológica, sejam fatores preponderantes. Anualmente, são gastos bilhões de dólares em todo o mundo para o tratamento de toxinfecções alimentares advindas de produtos comercializados in natura ou industrializados em feiras ou em atividade de comercialização de alimentos (Moretti, 2000).

Todo alimento pode sofrer contaminações químicas, físicas e biológicas, desde a sua origem até a chegada ao mercado consumidor. Muitas matérias-primas utilizadas na preparação de alimentos apresentam resíduos de defensivos agrícolas, antibióticos e hormônios. Nesse sentido, a contaminação biológica deve receber maior atenção, pois é responsável pela internação de centenas de pessoas, vitimas de quadros agudos de enfermidades transmitidas através dos alimentos (Manhoso, 1995).

Existem também os perigos químicos advindos dos produtos de higienização e de desintetização, quando estas operações não são conduzidas corretamente. Os perigos físicos, pregos, vidros e outros, são fonte de risco na produção e distribuição alimentos, e muitas vezes estão presentes porque se soltam de equipamentos, utensílios, bem como pedaços de vidros podem cair de lâmpadas ou objetos de vidro quebrados (SENAI, 1999).

As principais situações de perigo que o consumidor se depara ao adquirir e consumir são advindas dos perigos microbiológicos. Uma vez que o homem não consegue ver a olho nu os microorganismos, mas eles podem estar presentes no alimento (SENAI, 1999).

Os microorganismos estão presentes em todos os lugares e chegam aos alimentos pela falta de higiene, principalmente. Também chegam aos alimentos pela falta de higiene nos equipamentos e utensílios e por falta de cuidados na produção, comercialização, manuseio, transporte e conservação (SENAI, 1999).

Em locais como as feiras, os alimentos ficam expostos à poeira, insetos, sujidades e ao sol, indiretamente ou diretamente na superfície do produto. Problemas sanitários relacionados ao comércio de alimentos em feiras não decorrem de uma falha ou fato isolado, mas de um conjunto de atitudes inadequadas. Incluem-se neste contexto a falta de cuidados na escolha da matéria-prima, precárias condições de 
higiene no local de comercialização, dos equipamentos, utensílios e dos próprios feirantes (manipuladores), armazenamento inadequado da matéria-prima até o momento da comercialização (Germano et al., 1993).

Considerando a importância da matéria-prima estabelece-se métodos físicos de controle da qualidade em relação aos alimentos previamente comercializados. Dentre estes, destacam-se:

- manuseio adequado e cuidados inerentes ao alimento durante a colheita e pós colheita;

- melhoramento das técnicas e materiais de embalagem;

- uso de produtos agropecuários de boa qualidade;

- armazenamento rápido após colheita;

- sanitização e limpeza dos equipamentos agrícolas, máquinas , containers e armazéns;

- separação e remoção de produtos doentes;

- $\quad$ uso de refrigeração.

Considerando a relação entre a qualidade do alimento e a saúde pública, a Secretária de Vigilância Sanitária (SVS) por meio da Portaria n. ${ }^{\circ}$ 26/1997 estabeleceu alguns requisitos para a área de higiene e saúde; destacam-se:

- a necessidade do constante aperfeiçoamento das ações de controle sanitário na área de alimentos visando a proteção da saúde da população;

- a importância de compatibilizar a legislação nacional com base nos instrumentos harmonizados no Mercosul, relacionados às condições higiênicos-sanitários dos estabelecimentos produtores e comercializadores e as boas práticas de fabricação de alimentos.

O presente regulamento estabelece os requisitos gerais (essenciais) de higiene e de boas práticas de fabricação para alimentos produzidos/fabricados para o consumo humano. São eles:

1. princípios gerais higiênicos-sanitários das matérias-primas para alimentos produzidos/fabricados e comercializados. Inclui aspectos como área de produção, controle e prevenção da contaminação por 
lixos e sujidades, controle de água, pragas, doenças, remoção de matérias-primas impróprias, proteção contra contaminação das matérias-primas, armazenamento e transporte.

2. princípios gerais higiênicos-sanitários dos estabelecimentos produtores/comercializadores de alimentos. Inclui aspectos como localização, vias de acesso, equipamentos e utensílios, e higiene pessoal.

Como base também para análise no que diz respeito ao quesito qualidade e vigilância sanitária de alimentos deve-se considerar o Decreto $n^{\circ} 1588$ (Brasil, 1992),(Anexo 1) que discute sobre o regulamento da política de promoção, proteção e recuperação da saúde pelos meios de vigilância-sanitária e epidemiológica, abordando num contexto simples as normas para o funcionamento de feiras e a comercialização de alimentos.

Segundo o regulamento só poderão ser dados à venda ou expostos ao consumo, alimentos próprios para tal finalidade, devendo considerar o estado de conservação dos alimentos, sua natureza, composição e circunstâncias de produção, condicionamento e quaisquer atividades relacionadas aos mesmos; não devendo oferecer riscos, nem ter seu valor nutritivo prejudicado e não apresentar aspecto repugnante.

Por outro lado os estabelecimentos devem ser licenciados pelo órgão competente, que no caso das feiras do DF são registrados na administração local, obedecendo às disposições de legislação federal, estadual ou municipal relativas ao registro, bem como rotulagem, e padrões de identidade e qualidade.

Hoje os consumidores quando vão às feiras visam produtos de qualidade, expressa e definida por vários fatores, que geralmente influem na tomada da decisão, de forma a conseguir melhorias e a eficácia do atendimento ao consumidor.

Segundo Ferreira (1975), qualidade numa escala de valores, permite avaliar e consequentemente, aprovar, aceitar ou recusar determinado tipo de produto. A palavra qualidade agrupa um certo número de aspectos importantes para um entendimento global ou sistêmico do processo. Analisar e comparar a qualidade 
nesta perspectiva é uma tarefa complexa, porém permite uma maior probabilidade de acerto na escolha de um alimento mais adequado à saúde humana.

Para Crosby (1992), a qualidade pode ser definida como fruto do combate ao que chama de atividade comercial problema. Para Juram (1992), qualidade é a adequação ao uso, a conformidade às especificações e aos padrões.

Por outro lado, Eduards (1990) relata que qualidade significa tudo o que cada pessoa faz no negócio para satisfazer a totalidade dos requisitos de qualquer cliente, seja ele quem for. Segundo Ballestero (2001), devido à amplitude de conceitos, existem cinco preocupações que enfocam o quesito qualidade no mercado consumidor:

» Foco no padrão: a qualidade busca fazer com que o produto final segue o padrão estabelecido no projeto.

» Foco no uso: a qualidade busca satisfazer o uso que o consumidor deseja fazer do produto.

» Foco no custo: a qualidade procura associar a adequação do produto, custos cada vez mais baixos que proporcionem preços finais de venda, mais competitivos.

» Foco de desejo: a qualidade busca descobrir os desejos do mercado, enfocados por pesquisas.

» Foco no investimento: a qualidade passa a ter uma visão ampla do cliente, investidor, consumidor, que são vistos como organizações importantes na conquista de mercados.

Em todos os casos, a qualidade pode ser conceituada como adequação de um produto ao uso para o qual foi concebido. Geralmente, o que condiciona o fator qualidade é a satisfação do consumidor, e pode ser entendida como o atendimento a requisitos específicos em normas e regulamentos técnicos especialmente no que diz respeito aos aspectos de saúde, segurança e meio-ambiente (www.inmetro.gov.br, 2004).

Por este contexto, pode-se considerar que a satisfação do consumidor está relacionada com qualidade aos aspectos saúde, segurança e meio-ambiente. Para cada um deles, há um entendimento diferenciado sobre qualidade. $\mathrm{Na}$ área de 
saúde; a qualidade químico, além do nutricional, higiênico-sanitário, meio-ambiente pode ser entendida pelos aspectos:

Do ponto de vista nutricional, a qualidade está relacionado, com a presença de nutrientes que compõem esse alimento.

A qualidade higiênico-sanitário se refere à condição sanitária do produto, reflexo das características da matéria-prima e dos processos produtivos empregados. Refere-se à salubridade e à inocuidade do alimento, ou seja, à ausência de microorganismos (especialmente os patógenos), ou aqueles relacionados ao desperdício. O controle de qualidade sanitária de um alimento está relacionado à capacidade de serem controlados os fatores, que contribuem para a contaminação, sobrevivência e multiplicação de microrganismos. Para qualquer desvio das condições normais de operação é necessária a adoção de uma ação corretiva, a fim de garantir segurança no processo.

Entende-se por qualidade ambiental os processos por meio dos quais o indivíduo e a coletividade constróem valores sociais, conhecimentos, habilidades, atitudes e competências voltadas para a conservação do meio ambiente, bem de uso comum do povo, essencial à sadia qualidade de vida e sua à sustentabilidade, voltadas à sensibilização da coletividade sobre as questões ambientais e à sua organização e participação na defesa da qualidade do meio ambiente.

A busca da qualidade alimentar e a satisfação estão se tornando uma das principais preocupações dos consumidores conscientes. A principal motivação para este aspecto é o consumo de alimentos saudáveis que incorporam todos os requisitos mencionados devido ao fato de estarem completamente vinculados ao quesito qualidade, devendo ser o instrumento de promoção da saúde e qualidade de vida. 


\section{Metodologia}

\section{Materiais e Métodos:}

O trabalho é um estudo descritivo, transversal, que compreende as seguintes etapas: escolha e mapeamento das feiras, estimativa do número de bancas, pesquisa de satisfação dos usuários e levantamento do perfil das condições higiênico-sanitários e ambiental, com a lista de verificação nas feiras. Elaborou-se, um questionário para avaliar a satisfação dos usuários que freqüentam as feiras e posteriormente aplicado no período de fevereiro de 2004 a março de 2004. Para a caracterização do perfil higiênico-sanitário e ambiental das feiras, utilizou-se um roteiro observacional - lista de verificação das boas práticas de fabricação - RDC n²75 (Brasil, 2002), aplicado em cada uma das unidades visitadas em março de 2004.

Para a realização e desenvolvimento da pesquisa foram analisadas 3 feiras escolhidas não aleatoriamente, por serem as principais do Distrito Federal e entorno. As feiras escolhidas foram: Ceasa, Guará e Produtor. Em cada uma das feiras foi verificado o número de expositores para posterior definição da amostra no período de novembro 2003 a de janeiro de 2004.

A amostra em cada feira foi sistematizada de 10 em 10 expositores, sendo o expositor $\mathrm{n}^{\circ} 1$ o primeiro a participar da pesquisa. Quando o expositor sistematizado não se encontrava disponível, o próximo foi abordado. Em cada expositor foram entrevistadas 5 pessoas. Para cada feira o número de questionários aplicados foi de 25.

Para análise dos resultados foi utilizado o programa Excel para Windows para verificar a freqüência, e a média dos dados obtidos. 


\section{Resultados e Discussão}

Verificou-se que a freqüência do funcionamento das feiras é semanal geralmente aos sábado; por um período de aproximadamente seis horas de trabalho. Em média as três feiras têm 353 bancas, com venda direta de produtos variados.

A partir da constatação dos perigos analisados durante a pesquisa de satisfação dos consumidores e a lista de verificação da ANVISA, dentre os aspectos mais importantes quanto ao risco que a coletividade está sujeita, estão descritos os resultados em tópicos, como segue:

\subsection{Clientela Atendida}

A clientela é bastante variada; $76 \%$ do total de pessoas abordas foram do sexo feminino e $24 \%$ do sexo masculino. Em relação à faixa etária, $20 \%$ estão entre 20-30 anos e 80\% são maiores de 30 anos. A maioria das pessoas (40\%) têm uma receita mensal maior que 5 salários mínimos, o que pode significar que os consumidores primariamente estão preocupados com a conveniência de obtenção e de preço dos produtos, sem contudo atentar para os aspectos relativos à higiene, sanidade e qualidade (Garcia-Cruz et al., 2000; Mensah et al., 2002).

Para 54\% dos entrevistados o gasto mensal com alimentos nas feiras é de 50 a 75 reais. A ida dos usuários as feiras é de 4 vezes por mês (67\%). Os motivos pelos quais os consumidores freqüentam as feiras variam desde a possível compra de alimentos saudáveis e frescos, livres de agrotóxicos e até o fato da localização ser próxima ao local de residência, configurando um aspecto de comodidade, além de que, ir à feira pode ser ainda um atrativo lazer, por poder comprar com prazer e diversão, e estarem em um ambiente amistoso e agradável.

Por outro lado $40 \%$ dos entrevistados relataram que a pouca freqüência se devem a vários fatores; como a higiene inadequada do feirante, forma de atendimento, higiene do local, localização das feiras e preço dos alimentos. Como mostra a figura 1. Considerando a pesquisa de satisfação $100 \%$ de usuários abordados nas feiras 1, 2 e 3, 14\% acreditam que a higiene pessoal esta boa, 46\% regular, $15 \%$ muito fraco e $25 \%$ disseram que estava ruim (figura 1 ). 
A figura 1 representa a avaliação dos consumidores quanto à higiene pessoal dos feirantes.

O gráfico representa a condição dos feirantes quanto a higiene pessoal, os

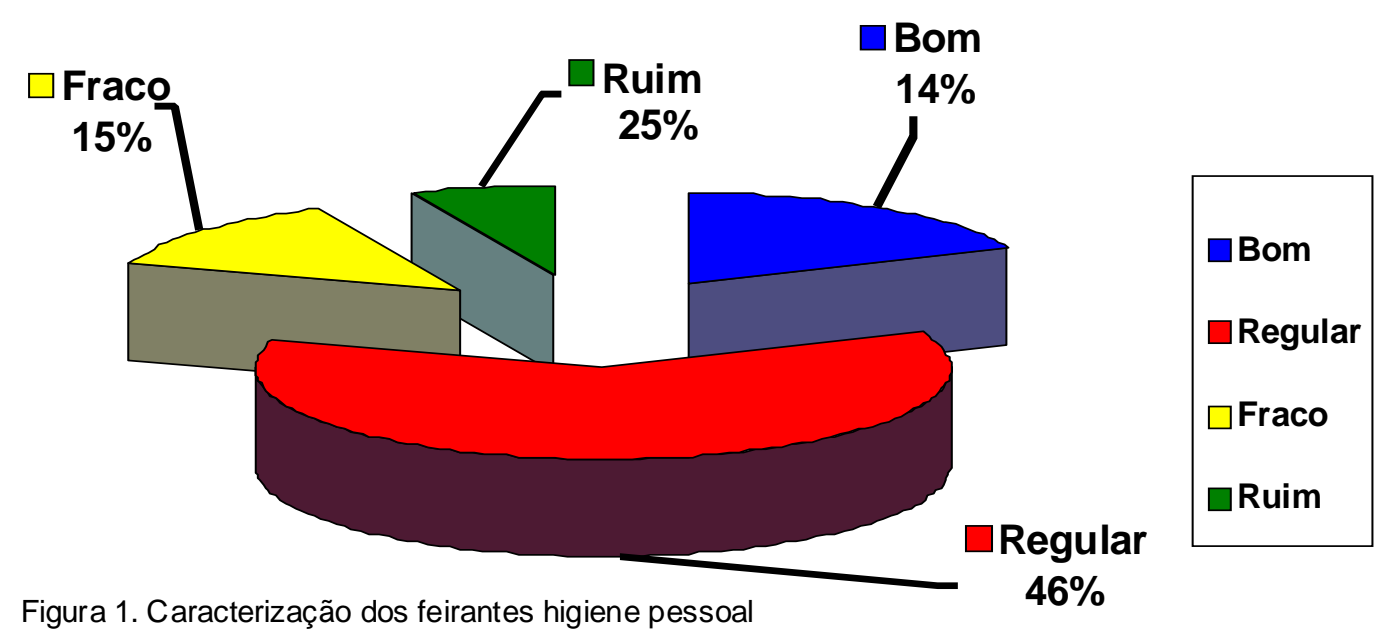

valores expressam claramente a falta de cuidados em relação a higiene.

Cabe ressaltar que os feirantes mostravam-se na maioria das bancas visualmente limpos, enquanto alguns não atendiam este requisito necessário para uma boa condição de higiene pessoal. Nem todos usavam jalecos sobre a roupa ou uniforme, muito menos adotavam qualquer cuidado com os cabelos, inclusive tinham o habito de coçar a cabeça constantemente e traziam as unhas grandes, sujas e também usavam adornos.

De fato a higiene pessoal é um dos fatores mais importantes para o atributo da qualidade, tendo em vista, que os feirantes devem estar conscientes e a própria administração local, bem como a associação dos feirantes. Melhores condições poderiam ser dadas pela administração que contribuíram para o desenvolvimento da capacitação de boas práticas higiênicas.

Outro fator importante abordado segundo a pesquisa de satisfação, foi o quesito infra-estrutura, 22\% dos entrevistados, relataram que é bom, 40\% regular, $23 \%$ diz que é fraco e 15\% acham que é ruim, configurando mais 1 vez o estado crítico de funcionamento (figura 2). 
A figura 2 representa a opinião dos população entrevistada segundo pesquisa de satisfação no quesito referente à infra-estrutura das feiras.

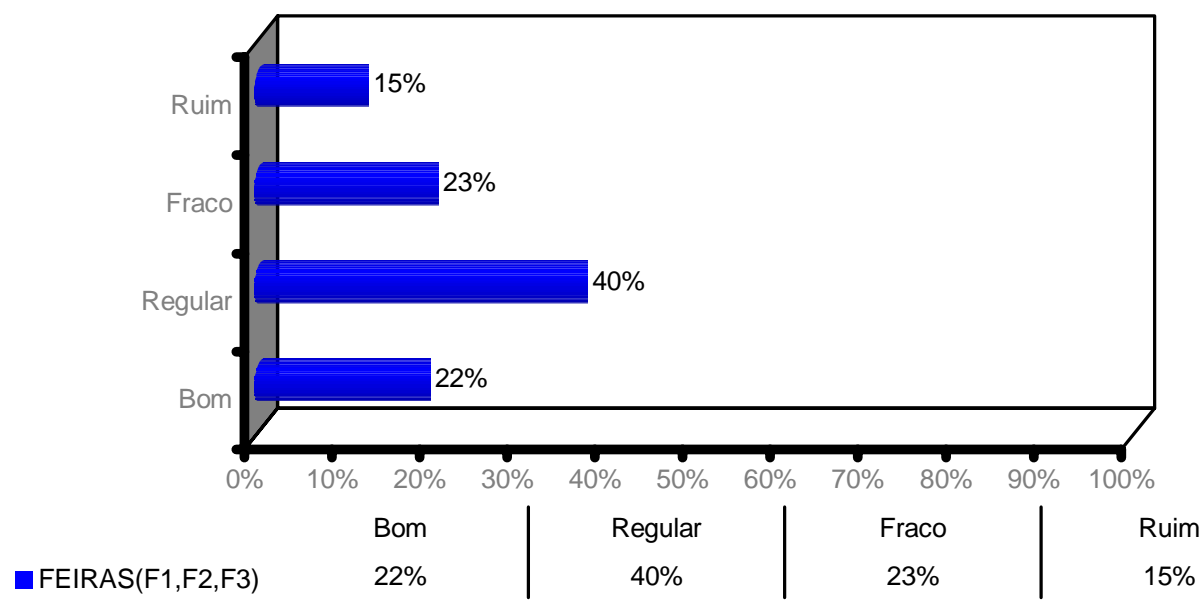

Figura 2. Características da infra-estrutura (Bancas, instalações, vias de acesso)

Os resultados apontaram para muitos problemas com 0 item acima mencionado, causando uma insatisfação entre os consumidores. Isto se deve ao fato de que existem sujidades, desperdício pelas sobras, configurando precárias condições de funcionamento. Por outro lado a pesquisa de satisfação demonstrou um outro resultado nada satisfatório, em relação a organização, higiene e limpeza das feiras, 14\% dos usuários disseram estar bom, 56\% dizem estar regular, 15\% acham estar fraco e $15 \%$ falaram que é ruim. (figura 3).

A figura 3 representa a opinião dos entrevistados quanto à organização, higiene e limpeza das feiras.

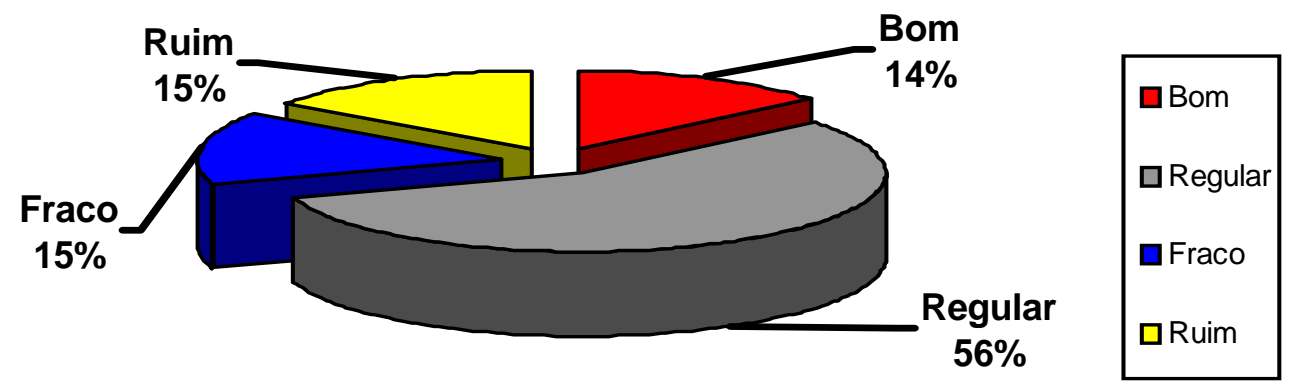

Figura 3. Organização, higiene e limpeza das feiras. Opinião dos usuários.

Contudo, segundo a pesquisa de satisfação, existe uma diferença entre as feiras F1 e F2, perfazendo (19\%), na qual o público consumidor dá preferência ao freqüentar a feira F2. Isto é em relação ao item mencionado acima. 


\subsection{Perfil higiênico sanitário das feiras-livres do DF}

A lista de verificação de boas práticas de fabricação, é um tipo de questionário observacional, utilizado pela Anvisa e pelas inspetorias de saúde, para avaliação e verificação de lugares que produzam, comercializam ou vendam alimentos. Após a aplicação do roteiro, cada estabelecimento pode ser classificado em um dos três grupos determinados pelo instrumento. A classificação geral das feiras foi realizada pela aplicação da lista de verificação e os resultados estão apresentados no quadro 1.

Quadro 1. Classificação das feiras-livres do DF conforme Roteiro Observacional (Lista de Verificação).

\section{Feiras}

F1

\section{classificação por grupo}

Grupo 3

\begin{tabular}{ll}
\hline \hline F2 & Grupo 3 \\
\hline \hline F3 & Grupo 3 \\
\hline \hline
\end{tabular}

* Classificação do estabelecimento: De 0 a 50 \% de itens atendidos: Grupo 3; de 51 a 75\% de itens atendidos Grupo 2 e de 76 a 100\% de itens atendidos Grupo 1.

Os critérios de pontuação para classificar os estabelecimentos que produzam, comercializam ou vendam alimentos são divididos em cinco blocos: edificações, equipamentos/utensílios, manipuladores, produção e manual. Verifica-se, para o referido estudo que os locais para a comercialização e venda dos produtos atenderam apenas até $50 \%$ dos itens apresentados na lista de verificação. Esses dados revelam, as precárias condições de funcionamento das feiras.

Os manipuladores de alimentos nas feiras-livres são os próprios feirantes, que simultaneamente manipulam alimentos e dinheiro, caixas e utensílios. As observações realizadas durante a pesquisa mostrou que havia em média de 4 a 6 pessoas, que se dividiam nas tarefas ou mesmo se alternavam durante o horário de funcionamento das feiras.

As operações executadas neste tipo de comércio, devem estar de acordo com o manual de boas práticas, juntamente com os procedimentos operacionais padrão. Infelizmente neste comércio de alimentos ainda não existe este tipo de manual. Isto é 
devido o não comprometimento da administração local e as autoridades fiscalizadoras, no desenvolvimento e aplicação da legislação pertinente.

Produção e transporte de alimentos, foi determinante para o resultado obtido nesta categoria. A razão se deve ao fato de não existir critérios estabelecidos para a seleção das matérias-primas baseados na segurança do alimento, bem como o transporte e armazenamento inadequados e embalagem sem rótulos.

Esses foram os principais quesitos da lista de verificação que apresentaram maior importância, influenciando claramente o resultado da análise. Entretanto não se pode deixar de lado os outros elementos, pois também influenciaram.

\subsection{Higiene das bancas, (utensílios, equipamentos) aquisição e armazenamento dos alimentos.}

Em referência a higienização das bancas, o constatado pela pesquisa de satisfação é que $10 \%$ dos consumidores disseram estar bom este aspecto, $50 \%$ acreditam estar regular, 15\% fraco e 25\% dizem que é ruim. Conforme figura 4.

Isto é denotado com o despreparo do feirante para o exercício da atividade, revelada pela insuficiente informação de como proceder na higienização correta e completa. Outro fator importante para aumentar a irregularidade são os serviços terceirizados prestados, que de tal forma é insatisfatório, contribuindo para o agravo na limpeza da área interna e externa local. Isto se deve pela falta de fiscalização das autoridades sanitárias e também, haja vista a falta de recursos da administração local e da associação dos feirantes, que nem se preocupam em capacitar os seus colaboradores.

A figura 4 representa a opinião da população entrevistada quanto à higiene das bancas e do local de armazenamento dos alimentos nas feiras.
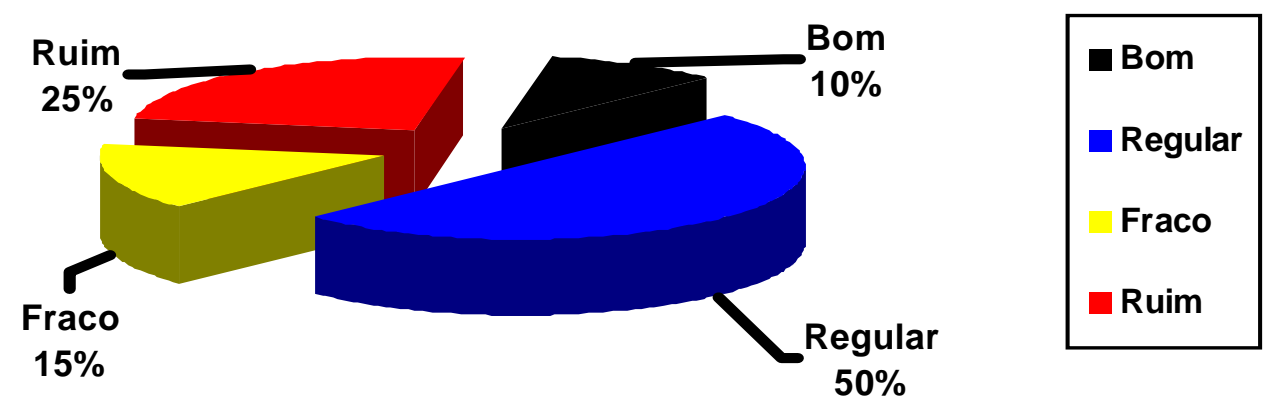

Figura 4. Higiene das bancas (utensílios, equipamentos) aquisição e armazenamento dos alimentos. 
Para minimizar estes problemas Hazelwood (1994) sugere indicadores higiênico-sanitários que possam orientar o profissional visando melhoria das condições neste tipo de estabelecimento.

De acordo com os feirantes de todas as feiras, a limpeza dos equipamentos, utensílios e recipientes, não acontecem nas bancas, sendo todo o material levado para casa, local destinado para a etapa de higienização. Porém foi constatado em alguns momentos durante visita nas feiras, o uso de panos umedecidos para a limpeza superficial de equipamentos e utensílios. As águas descartadas de lavagem eram jogadas no chão ou ao redor das bancas.

Neste cenário é oportuno colocar a preocupação expressa por HUAMÁN (2002), quanto ao destino de águas resultantes da preparação de alimentos e da lavagem de vasilhames, visto que, em geral, são lançados em bueiros ou jogados diretamente em vias públicas, jardins e terrenos baldios. Segundo o autor essas águas, constituem fator crítico para a contaminação ambiental ao redor das feiras, por apresentarem resíduos de alimentos e atraírem insetos e roedores.

Para a maior parte dos feirantes a aquisição dos alimentos é realizada na pedra, local de comercialização de mercadorias no atacado, produzidos por produtores do entorno. Grande parte dos feirantes são produtores.

Os alimentos perecíveis como hortifruti, são vendidos in natura no varejo e expostos em prateleiras de madeira ou ferro, ou estando armazenados em caixas tipo k, caixa de madeira. Embora existam algumas bancas que utilizam as caixas plásticas, estas são comportadas no chão embaixo da banca, considerando fator de risco para contaminações. Contudo se viu em 1 das feiras a comercialização de aves abatidas, armazenadas em sacos plásticos (PVC) de espessura fina, vendidas sem nenhuma condição de conservação e embalagem correta.

Já alimentos semi-perecíveis como grãos, eram vendidos e armazenados em sacarias, com identificação adequada. Entretanto ao redor do ambiente onde os produtos eram expostos, apresentavam algum tipo de sujidade, condicionando desta maneira falta de condição higiênico-sanitária para a circulação e armazenamento dos mesmos. 
Em paralelo a estas questões, considerando a figura 4, é visível a insatisfação dos consumidores, pois se mostram bastante inadequadas a higienização das bancas, o armazenamento de alimentos, bem como o acondicionamento dos produtos e sua comercialização, visto que há presença de sujidades.

\subsection{Características da infra-estrutura e organização (instalações, bancas, vias de acesso) das feiras.}

As instalações das feiras-livres são localizadas em lugar público, previamente designado pela administração local, onde as vias de acesso na maioria estão em precárias condições de uso, estando próximo ao trânsito de pessoas e de veículos. Nas imediações foi observada a presença de lixo e de entulho. Neste sentindo, considera-se a localização extremamente inadequada, em virtude das feiras estarem sujeitas a diversas formas de contaminação, como poeira, fumaça, odores e outras fontes insalubres.

A infra-estrutura das feiras analisadas, é composta e constituída de armação metálica do tipo pavilhão, não havendo coberturas laterais nem paredes. Entretanto no caso de peixarias e açougues existem requisitos próprios como paredes laterais para a proteção. No interior das feiras, as bancas eram na maior parte de armações metálicas, exceto na F2 em que as bancas eram basicamente armações de madeira. Não havia nenhum forro compondo as armações onde os alimentes estavam expostos.

O suprimento de água é realizado pela rede da Caesb, em todas as feiras pesquisadas. Não há no interior das feiras qualquer instalação de pias. No caso específico do uso de sanitários, os feirantes, bem como os consumidores, encontram os banheiros na parte externa do local.

Sobre as edificações e instalações verificou-se que o principal aspecto que interfere na condição de sanidade, é que a área fique livre de focos de insalubridade. De modo geral verificou-se não haver a existência de lixeiras instaladas nas bancas, ao redor do local e muito menos próximo às feiras, sendo os resíduos, sobras de alimentos impróprios para o consumo, armazenados em cantos ou até jogados no chão. Há também a presença de catadores de lixo, que é destinado à coleta pública. O lixo bruto fica em containers distantes do local. 
Pela descrição, notam-se situações que evidenciam riscos na exposição, comercialização e venda. Os produtos vindos das propriedades familiares, direto para às feiras, não trazem qualquer referência quanto a sua origem e qualidade colocando em dúvida a condição higiênico-sanitária. Se por um lado, os produtos passam por colheita, pós colheita, manuseio e transporte, entre outros fatores que os expõem a contaminação, por outro, é evidente que o despreparo em relação a higiene do feirante, higiene das bancas e higiene local afetam por conseguinte 0 funcionamento do local inteiro, em virtude dos aspectos que determinam a sanidade.

Apesar de apresentar, por um lado, possível impacto positivo na segurança alimentar, na medida em que gera empregos e diminui a pobreza, à venda de alimentos nestas feiras representam riscos à inocuidade alimentar, bem como afetam a saúde da população, pela condição sanitária dos produtos comercializados, tendo em vista fatores intrínsecos e extrínsecos, que contribuem para a insalubridade do local e dos alimentos consumidos. 


\section{Conclusão}

O presente estudo contribuiu para avaliação da satisfação de consumidores e descrição da qualidade higiênico-sanitária das feiras-livres ou permanentes no Distrito Federal, que comercializam principalmente alimentos entre outros produtos e serviços. As feiras (F1, F2, F3) foram verificadas de tal forma para identificar os riscos na comercialização, operações de controle e adequação destes estabelecimentos.

Constatou-se que as possibilidades de contaminações são comuns a todos os alimentos, pela precariedade do ambiente, das instalações físicas, dos, equipamentos, dos utensílios e móveis, bem como da falta de treinamento para adequar o recebimento da matéria-prima. Com isso reduz-se sensivelmente 0 conceito dos estabelecimentos visitados, sendo que se apresentaram insatisfatórios do ponto de vista físico e higiênico-sanitário.

Para tornar satisfatórias as condições de comercialização nestas feiras, é imprescindível que se faça a capacitação dos feirantes (manipuladores) com relação a segurança alimentar para que desempenhem seu papel no oferecimento de alimentos, produtos e serviços com qualidade. Deve-se aumentar e desenvolver o conhecimento por parte dos mesmos, aprimorando e fortalecendo as práticas higiênico-sanitárias. A administração local, a associação dos feirantes/produtores e a própria vigilância sanitária poderiam oferecer de certa forma um treinamento, desenvolvendo as técnicas necessárias para a capacitação.

O treinamento constante e o monitoramento sistemático da produção e das boas práticas higiênicas colaboram para a redução do risco de doenças que venham a ocorrer devido à colheita, transporte, manipulação, exposição, conservação e armazenamento incorreto dos alimentos nestas feiras.

O ponto principal para que haja melhoria da qualidade na comercialização dos alimentos nestas feiras, é enfatizar cada vez mais o trabalho dos órgãos de fiscalização, vigilância sanitária, dos agentes de saúde e conscientizar os feirantes e seus colaboradores da importância de existir segurança alimentar e posteriormente agregar qualidade em seus alimentos, produtos e serviços. 
Segundo a pesquisa de satisfação, de acordo com os dados resultantes da avaliação, foi possível confirmar a insatisfação por parte dos consumidores, além disso o comprometimento dos órgãos fiscalizadores e da própria administração local em deixar às feiras em condições inadequadas de funcionamento, somadas às irregularidades e características de não conformidade colocados anteriormente, reforçam o risco existente neste comércio de alimentos.

Tendo em conta a clientela atendida por este serviço, bem como as características observadas tanto na pesquisa de satisfação. quanto na lista de verificação, estes resultados sinalizam e atentam para o risco potencial quanto à veiculação de doenças de origem alimentar.

Mediante o quadro, torna-se essencial à adoção de medidas de caráter público, que contribuam para a aplicação da legislação pertinente e para a realização de trabalhos educativos junto aos feirantes e consumidores, enfatizando a importância de minimizar os riscos e erros, a fim de manter a sanidade e qualidade nos alimentos comercializados nas feiras. 


\section{Bibliografia}

AYRES, C.; KOMINSKY, G.; MELLO, A.; SCHMITT, J.U. Avaliação da condição higiênico-sanitária de restaurantes comerciais de Porto Alegre frente à legislação Vigente. Revista Higiene Alimentar, São Paulo, v17, n104/105, jan. 2003, p.16-17.

BALLESTERO-ALVAREZ, M.E. Administração da qualidade e da produtividade. Abordagens do processo administrativo. São Paulo: Atlas, 2001.

BRASIL. Distrito Federal. Lei $\mathrm{n}^{\circ} 1828$, de 13 de Janeiro de 1998 . Disciplina a Organização e o Funcionamento das Feiras livres e permanentes no Distrito Federal. D.O.DF 13/01/98. Disponível em:<http//: www.sucar.df.gov.br/l1828.htm>. Acesso em: 25 out. 2003.

BRASIL. Ministério da Agricultura, Pecuária e abastecimento. Plano Agrícola e Pecuário. Safra 2003/2004. Brasília: MAPA/SPA, 2003. 80p.

BRASIL. Ministério da Saúde. Decreto n¹588 de 28 de Dezembro de 1992. Regulamento da política de promoção, proteção e recuperação da saúde, vigilância sanitária e epidemiológica no Município de Goiânia. D.O.M de Goiânia n¹016 de 20/12/92. Disponível em: <http:// www.anvisa.gov.br/base/visadoc/dec/dec[2695-10].htm>. Acesso em: 25 out. 2003.

BRASIL. Ministério da Saúde. Portaria SVS/MS n³26, de 30 de julho de 1997. Regulamento Técnico sobre as Condições Higiênico-Sanitárias e de boas Práticas de Fabricação para Indústrias de Alimentos. D.O.U de 01/08/97.

BRASIL. Ministério da Saúde. Agência nacional de vigilância sanitária. RDC n²75, de 21 de outubro de 2002. Regulamento técnico de procedimentos operacionais padronizados aplicados aos estabelecimentos produtores/ industrializadores de alimentos e a lista de verificação das boas práticas de fabricação em estabelecimentos produtores/industrializadores de alimentos. Republicado no D.O.U de 06/11/2002. 
BUARQUE, A.H.F. Novo Dicionário Aurélio da Língua Portuguesa. $1^{\circ}$ edição, $15^{a}$ impressão. Rio de Janeiro: Editora Nova fronteira. 1975.

BRITO ON LINE. Servis para relações livres de trabalho. Disponível em: <http:// www.lasalle.g12.br/ensino/brito/cap31.htm>, acesso em: 7 abr. 2004.

CONTINUAÇÃO 1. O Regaste Da Evolução do Trabalho, Ocupação e Emprego. Disponível em: <http://www.eps.ufsc.br/teses98/ester/cap2a.htm>. Acesso em 7 abr. 2004.

CROSBY, PHILIP B. Qualidade sem lágrimas. $2^{\circ}$ ed. Rio de Janeiro: José Olympio, 1992.

DEMING, W. EDWARDS. Qualidade a revolução da administração. Rio de Janeiro: Marques-Saraiva, 1990.

GARCIA-CRUZ, C.H.; HOFFMANN, F.L.; BUENO, S.M. Monitoramento microbiologico de lanches vendidos por ambulantes na parte central de cidade de São José do Rio Preto, SP. Revista Higiene alimentar, São Paulo. v14, n75, p 4851. 2000.

GERMANO, P.M.L.; MIGUEL, M.; MIGUEL, O.; GERMANO, M.I.S. Prevenção e controle das toxinfecções de origem alimentar. Revista Higiene Alimentar. São Paulo. v7, n27, Ago.1993.

HALWOOD, D.; MCLEAN, A.C. Manual de higiene para manipuladores de alimentos. São Paulo: Varela, 1994. 140p.

HISTÓRICO, das feiras livres na cidade do rio de Janeiro. Prefeitura Rio. Copyright $@$ 1999. by Coordenação de Licenciamento e Fiscalização. Disponível em: <http://www.rio.rj.gov.br/clf/feiras/historia.htm>. Acesso em: 25 out. 2003.

HUAMÁN, J.P. Las tecnologias apropriadas para la venta callejera de alimentos.Disponívelem:<http://www.fao.org/docrep/w0073e/w3699T/ww3699t09.ht m>. Acesso em: 7 abr. 2004. 
INMETRO. QUALIDADE. Disponível em: <www.inmetro.gov.br/qualidade/index.asp>. Acesso em: 7 abr. 2004.

JURAM, J.M. Planejamento para a qualidade. $2^{\circ}$ ed. São Paulo: Pioneira, 1992.

LUFT, CELSO PEDRO. Pequeno Dicionário da Língua Portuguesa. São Paulo: Scipione Autores e Editores. 1984.

MANHOSO, F.F.R. Aspectos químicos e microbiológicos das lingüiças tipo frescal no Brasil. Revista Higiene Alimentar, São Paulo. v9, n39, set. / out. 1995.

MENSAH, P.; YEBOAH-MANU, D.; OWUSU-DARKO, K. et al. Street foods in Accra, Ghana: how safe are they?. Bull World Health Organ. v.80, n7, p.546-554. Jul. 2002.

PRODAM. Prefeitura, SP - Feiras. Copyright (C SEMAB. Março/2000. Disponível em: <www.prodam.sp.gov.br/semab/mercados/feiras.htm>. Acesso em: 25 out. 2003.

QUINTAES, K.D.; VARGAS, D.S.T. Comportamento da temperatura de pescados expostos em bandejas de aço inoxidável em feiras livres de São Paulo. Nutrição Brasil. 3(1). jan. / fev. 2004.

SENAI. Trabalhando com segurança na produção de alimentos. Rio de Janeiro, SENAI/DN. 32p (Série Qualidade e Segurança Alimentar) Projeto APPCC. Convênio CNI/SENAI/SEBRAE. 1999. 
8. ANEXOS 
Anexo 1. PORTARIA SVS/MS N²6/1997.

\section{Na parte VII Dos Gêneros Alimentícios, Capitulo I; Das Considerações Iniciais e Definições Diz:}

Art. 217- os assuntos pertinentes à defesa e a proteção da Saúde individual coletiva, no que concerne alimentos, em todas as etapas de sua produção até o consumo no comercio, serão regulados em todos os aspectos pelas disposições deste regulamento.

Art. 218 - para os efeitos desta regulamentação considera-se:

I - alimento: toda substancia ou mistura no estado sólido, liquido, pastoso ou qualquer outra forma adequada, destina a fornecer ao organismo humano os elementos normais à sua formação, manutenção e desenvolvimento

II - matéria-prima alimentar: toda substância de origem vegetal ou animal, no estado bruto, para ser utilizado como alimento, precisa sofre tratamento ou transformação de natureza, química, física ou biológica.

III - alimento in natura : todo alimento de vegetal ou animal para o consumo imediato se exijam, apenas, a remoção da parte não comestível e os tratamentos indicados para sua perfeita higienização e conservação.

No entanto, considerado o disposto vamos relatar alguns itens no quesito que aborda o Capitulo VI do regulamento que fala Da Vigilância e Fiscalização de alimentos.

Art. 240 - a ação fiscalizadora será exercida pelas autoridades federais, estaduais e municipais, no âmbito de suas atribuições.

Art. 241 - a fiscalização da autoridade sanitária será exercida sobre os alimentos, o pessoal que os manipula e sobre os locais e instalações onde se comercializam, fabricam, produzem, transportam, beneficiam, manipula, acondicionam, conservam, depositam, armazenam ou consumam alimentos.

$1^{\circ}$ Além de apresentar em perfeitas condições para o consumo, os produtos substâncias, insumos ou outros, deverão ser oriundos de fontes aprovadas ou autorizadas pela autoridade sanitária competente. 
$\mathbf{2}^{\circ}$ Os alimentos perecíveis devem ser transportados, armazenados ou depositados em condições de temperatura, umidade, ventilação e luminosidade que protejam de contaminações e deteriorações.

$3^{\circ}$ No fabrico, produção, beneficiamento, manipulação, acondicionamento, conservação, armazenamento, depósito, transporte, distribuição, venda, compra e consumo de alimentos, deverão ser observados rigorosamente preceitos de higiene e limpeza.

Art. 242 - os gêneros alimentícios devem, obrigatoriamente, ser protegidos por invólucros próprios e adequados no armazenamento, transporte, exposição e comércio.

$1^{\circ}$ No acondicionamento de alimentos não é permitido o contato direto com jornais, papeis tingidos ou filmes plásticos com face empressa e sacos destinados ao acondicionamento de lixo.

$2^{\circ}$ Os gêneros alimentícios, que por força da sua comercialização, não puderem ser completamente protegidos por invólucros, devem ser abrigados em dispositivos adequados a evitar a contaminação, e serem manuseados ou servidos mediante o emprego de utensílios ou outros dispositivos que sirvam para evitar o contato com as mãos.

$3^{\circ}$ A sacarias utilizadas no acondicionamento de alimentos, devem ser de primeiro uso, sendo proibido o emprego de embalagens que já tenham sido usadas para produtos comestíveis etc.

Art. 248 - as peças, maquinários, equipamentos, utensílios, recipientes, embalagens e outros que venham a entrar em contato com alimentos nas diversas fases de produção, manipulação e comercialização e outras quaisquer situações que intervêm nocivamente com os mesmos, alterar o valor nutritivo, ou as suas características organolépticas, devendo ser mantidas limpas e livres de sujidades, poeiras insetos e outras fontes de contaminação.

Art. 252 - nenhum alimento poderá ser exposto à venda sem estar convenientemente protegido contra poeira, insetos e outros animais. 
Art. 255 - os alimentos susceptíveis, de fácil contaminação, comercializados em feiras ou ambulantes, como leite, produtos lácteos, maionese, carnes e produtos do mar, deverão ser conservados em refrigeração adequados.

Art. 257 - o destino dos restos de alimentos, sobras intactas e lixo, nos locais onde se manipule, comercialize ou processe os produtos, devem obedecer as técnicas recomendadas pelas autoridades sanitárias.

\section{Considerando o capítulo XII que aborda explicitamente às Feiras diz;}

Art. 331 - todos alimentos à venda nos estabelecimentos deve estar agrupados de acordo com sua natureza e protegidos da ação dos raios solares, chuvas e outras intempéries, ficando terminantemente proibido colocá-los diretamente sobre o solo.

Art. 332 - nestes estabelecimentos é permitida á venda a varejo de produtos hortifrutigranjeiros e subsidiariamente de outros alimentos observadas as seguintes exigências;

I - devem ser mentidos em refrigeração nas temperaturas exigidas, respectivamente, o alimentos obrigados a esse tipo de conservação.

II - a comercialização de carnes, pescados e derivados e produtos da laticínios, passíveis da refrigeração, será permitida, desde que em veículos frigoríficos, que serão vistoriados e aprovados pela autoridade sanitária, ou em balcões frigoríficos, devidamente instalados e em perfeito funcionamento e providos de portas apropriadas, que deverão ser mantidas fechadas.

III - os veículos, barracas e balcões para a comercialização de carnes ou pescados devem dispor de deposito suficiente para o abastecimento de água corrente.

IV - é proibido o deposito e a comercialização de aves ou animais vivos

V - bancas devem ser impermeabilizadas com material adequado para conter produtos alimentícios como hortifrutigranjeiros.

VI - fica proibido o fabrico de alimentos. 
Anexo 2 (Pesquisa de Satisfação)

Pesquisa de satisfacão

Para identificar o fator qualidade na feira gostaríamos de saber sua opinião:

1. Sexo F $\square_{\text {M }} \square_{\text {Idade: }} \square_{<20} \square_{20-30} \square_{>30}$

2. Renda salarial mensal?

$<$ de um salário

1 até 1,9 salários

2 até 2,9 salários

3 até 3,9 salários

4 até 4,9 salários

$>5$ salários
Localização da Feira:

Número da Ficha:

Data:

Local onde Mora:

Horário da Entrevista:

3. Quantas vezes você freqüenta a feira por mês?

1 vez $\square 2$ vezes $\square 3$ vezes $\square 4$ vezes $\square$ +de 4 vezes

4. Qual é o gasto por vez estabelecido na compra de alimentos? (R\$)

$<10 \square 10$ a $25 \square 25$ a $50 \square 50$ a $75 \square 75$ a $100 \square>100$

5. Como você classifica está feira em relação ao aspecto higiene pessoal do feirante?

Ótimo $\square$ Bom $\square$ Regular $\square$ Fraco $\square$ Ruim

6. Como você classifica está feira em relação a higiene do ambiente dos boxes onde são colocados e armazenados os alimentos?

Ótimo $\square$ Bom $\square$ Regular $\square$ Fraco $\square$ Ruim

7. Como você classifica o aspecto transporte (vias de acesso e transporte público disponível) ao acesso desta feira?

Ótimo $\square$ Bom $\square$ Regular $\square$ Fraco $\square$ Ruim

8.Como você classifica a localização desta feira ?:

Ótimo $\square$ Bom $\square$ Regular $\square$ Fraco $\square$ Ruim $\square$

9. Como você classifica o aspecto infra-estrutura (Bancas, boxes, cobertura caso exista, pisos, sanitários, pias etc.) nesta feira?

Ótimo $\square$ Bom $\square$ Regular $\square$ Fraco $\square$ Ruim

10. Como você classifica a organização, higiene e limpeza nesta feira como um todo? Ótimo $\square$ Bom $\square$ Regular $\square$ Fraco $\square$ Ruim $\square$

11. Você está disposto a pagar mais por um aumento da qualidade na feira em todos aspectos acima mencionados? Sim $\square$ Não

12. De forma geral você está satisfeito com a feira que freqüenta? Sim $\square$ Não $\square$ Porquê?

13. Por que freqüenta esta feira? 


\section{Anexo 3 (RDC n²75 Roteiro Observacional Lista de Verificação ANVISA)}

Resolução - RDC n² 275, de 21 de outubro de 2002(*)

Republicada no D.O.U de 06/11/2002

Dispõe sobre o Regulamento Técnico de Procedimentos Operacionais Padronizados aplicados aos Estabelecimentos Produtores/Industrializadores de Alimentos e a Lista de Verificação das Boas Práticas de Fabricação em Estabelecimentos Produtores/Industrializadores de Alimentos.

A Diretoria Colegiada da Agência Nacional de Vigilância Sanitária no uso da atribuição que Ihe confere 0 art. 11, inciso IV, do Regulamento da ANVISA aprovado pelo Decreto $\mathrm{n}^{\circ} 3.029$, de 16 de abril de 1999, c/c o $\S 1^{\circ}$ do art. 111 do Regimento Interno aprovado pela Portaria $n^{\circ}$ 593 , de 25 de agosto de 2000 , republicada no DOU de 22 de dezembro de 2000 , em reunião realizada em 16 de outubro de 2002,

considerando a necessidade de constante aperfeiçoamento das ações de controle sanitário na área de alimentos visando a proteção à saúde da população;

considerando a necessidade de harmonização da ação de inspeção sanitária em estabelecimentos produtores/industrializadores de alimentos em todo o território nacional;

considerando a necessidade de complementar o Regulamento Técnico sobre as Condições Higiênico-Sanitárias e de Boas Práticas de Fabricação para Estabelecimentos Produtores/Industrializadores de Alimentos;

considerando a necessidade de desenvolvimento de um instrumento genérico de verificação das Boas Práticas de Fabricação aplicável aos estabelecimentos produtores/industrializadores de alimentos;

considerando que a Lista de Verificação restringe-se especificamente às Boas Práticas de Fabricação de Alimentos;

considerando que a atividade de inspeção sanitária deve ser complementada com a avaliação dos requisitos sanitários relativos ao processo de fabricação, bem como outros que se fizerem necessários;

considerando que os estabelecimentos podem utilizar nomenclaturas para os procedimentos operacionais padronizados diferentes da adotada no Anexo I desta Resolução, desde que obedeça ao conteúdo especificado nos mesmos,

adota a seguinte Resolução de Diretoria Colegiada e eu, Diretor-Presidente, determino a sua publicação:

Art. $1^{\circ}$ Aprovar o Regulamento Técnico de Procedimentos Operacionais Padronizados aplicados aos Estabelecimentos Produtores/Industrializadores de Alimentos e a Lista de Verificação das Boas Práticas de Fabricação em Estabelecimentos Produtores/Industrializadores de Alimentos.

Art. $2^{\circ}$ As empresas têm o prazo de 180 (cento e oitenta) dias, a contar da data de publicação, para se adequarem ao Regulamento Técnico de Procedimentos Operacionais Padronizados aplicados a Estabelecimentos Produtores/Industrializadores de Alimentos, constante do Anexo I desta Resolução.

Art. $3^{\circ} \mathrm{A}$ avaliação do cumprimento do Regulamento Técnico constante do Anexo I e do Regulamento Técnico sobre as Condições Higiênico-Sanitárias e de Boas Práticas de Fabricação para Estabelecimentos Produtores/Industrializadores de Alimentos, aprovado pela Portaria SVS/MS n 326, de 30 de julho de 1997, dar-se-á por intermédio da Lista de 
Verificação das Boas Práticas de Fabricação em Estabelecimentos Produtores/Industrializadores de Alimentos constante do Anexo II.§ $1^{\circ}$ Os estabelecimentos devem atender de imediato a todos os itens discriminados na Lista de Verificação das Boas Práticas de Fabricação em Estabelecimentos Produtores/Industrializadores de Alimentos.

$\S 2^{\circ}$ Excetuam-se do prazo estipulado no parágrafo anterior os itens relativos ao Regulamento Técnico de Procedimentos Operacionais Padronizados aplicados a Estabelecimentos Produtores/Industrializadores de Alimentos sendo considerado o prazo de adequação estipulado no art. $2^{\circ}$.

Art. $4^{\circ}$ A Lista de Verificação das Boas Práticas de Fabricação em Estabelecimentos Produtores/Industrializadores de Alimentos, constante do Anexo II, não se aplica aos estabelecimentos que apresentem regulamento técnico específico.

Art. $5^{\circ} \mathrm{O}$ atendimento dos requisitos constantes da Lista de Verificação das Boas Práticas de Fabricação não exclui a obrigatoriedade das exigências relativas ao controle sanitário do processo produtivo.

Art. $6^{\circ}$ A inobservância ou desobediência ao disposto na presente Resolução configura infração de natureza sanitária, na forma da Lei n 6437, de 20 de agosto de 1977, sujeitando 0 infrator às penalidades previstas nesse diploma legal.

Art. $7^{\circ}$ Esta Resolução de Diretoria Colegiada entrará em vigor na data de sua publicação.

GONZALO VECINA NETO

ANEXO I

REGULAMENTO TÉCNICO DE PROCEDIMENTOS OPERACIONAIS PADRONIZADOS APLICADOS AOS ESTABELECIMENTOS PRODUTORES/INDUSTRIALIZADORES DE ALIMENTOS

ALCANCE

\subsection{Objetivo}

Estabelecer Procedimentos Operacionais Padronizados que contribuam para a garantia das condições higiênico-sanitárias necessárias ao processamento/industrialização de alimentos, complementando as Boas Práticas de Fabricação

\section{2. Âmbito de Aplicação}

Aplica-se aos estabelecimentos processadores/industrializadores nos quais sejam realizadas algumas das seguintes atividades: produção/industrialização, fracionamento, armazenamento e transporte de alimentos industrializados

\section{DEFINIÇÕES}

Para efeito deste Regulamento, considera-se:

2.1. Procedimento Operacional Padronizado - POP: procedimento escrito de forma objetiva que estabelece instruções seqüenciais para a realização de operações rotineiras e específicas na produção, armazenamento e transporte de alimentos. Este Procedimento pode apresentar outras nomenclaturas desde que obedeça ao conteúdo estabelecido nesta Resolução.

2.2. Limpeza: operação de remoção de terra, resíduos de alimentos, sujidades e ou outras substâncias indesejáveis.

2.3. Desinfecção: operação de redução, por método físico e ou agente químico, do número de microrganismos a um nível que não comprometa a segurança do alimento. 
2.4. Higienização: operação que se divide em duas etapas, limpeza e desinfecção.

2.5. Anti-sepsia: operação destinada à redução de microrganismos presentes na pele, por meio de agente químico, após lavagem, enxágüe e secagem das mãos.

2.6. Controle Integrado de Pragas: sistema que incorpora ações preventivas e corretivas destinadas a impedir a atração, o abrigo, o acesso e ou proliferação de vetores e pragas urbanas que comprometam a segurança do alimento.

2.7. Programa de recolhimento de alimentos: procedimentos que permitem efetivo recolhimento e apropriado destino final de lote de alimentos exposto à comercialização com suspeita ou constatação de causar dano à saúde.

2.8. Resíduos: materiais a serem descartados, oriundos da área de produção e das demais áreas do estabelecimento.

2.9. Manual de Boas Práticas de Fabricação: documento que descreve as operações realizadas pelo estabelecimento, incluindo, no mínimo, os requisitos sanitários dos edifícios, a manutenção e higienização das instalações, dos equipamentos e dos utensílios, o controle da água de abastecimento, o controle integrado de vetores e pragas urbanas, controle da higiene e saúde dos manipuladores e o controle e garantia de qualidade do produto final.

\section{REFERÊNCIAS}

3.1. BRASIL. Decreto-Lei no 986, de 21 de outubro de 1969. Institui Normas Básicas sobre Alimentos.

3.2. BRASIL. Lei $n^{\circ} 6437$, de 20 de agosto de 1977, e suas alterações. Configura infrações a legislação sanitária federal, estabelece as sanções respectivas e dá outras providências.

3.3. BRASIL. Ministério da Saúde. Secretaria de Vigilância Sanitária. Portaria $n^{\circ} 326$, de 30 de julho de 1997. Regulamento Técnico sobre as Condições Higiênico-Sanitárias e de Boas Práticas de Fabricação para Indústrias de Alimentos.

3.4. BRASIL. Ministério da Saúde - Secretário Nacional de Organização e Desenvolvimento de Serviços de Saúde. Programa de Controle de Infecção Hospitalar. LAVAR AS MÃOS: INFORMAÇÕES PARA PROFISSIONAIS DE SAÚDE. 39 páginas na Impressão Original, il. - Série A: Normas e Manuais Técnicos - 11, 1989.

3.5. BRASIL. Ministério da Saúde. Secretaria de Vigilância Sanitária. Portaria $n^{\circ} 1.428$, de 26 de novembro de 1993. Regulamentos Técnicos sobre Inspeção Sanitária, Boas Práticas de Produção/Prestação de Serviços e Padrão de Identidade e Qualidade na Área de Alimentos.

3.6. BRASIL. Ministério da Saúde. Agência Nacional de Vigilância Sanitária. Resolução-RDC $n^{\circ} 18$, de 29 de fevereiro de 2000. Dispõe sobre Normas Gerais para funcionamento de Empresas Especializadas na prestação de serviços de controle de vetores e pragas urbanas.

3.7. BRASIL. Ministério da Saúde. Agência Nacional de Vigilância Sanitária. Resolução $n^{\circ} 22$, de 15 de março de 2000. Dispõe sobre o Manual de Procedimentos Básicos de Registro e Dispensa da Obrigatoriedade de Registro de Produtos Importados Pertinentes à Área de Alimentos.

3.8. BRASIL. Ministério da Saúde. Agência Nacional de Vigilância Sanitária. Resolução $n^{\circ} 23$, de 15 de março de 2000. Dispõe sobre o Manual de Procedimentos Básicos para Registro e Dispensa da Obrigatoriedade de Registro de Produtos Pertinentes à Área de Alimentos.

3.9. CODEX ALIMENTARIUS. CAC/RCP 1-1969, Ver. 3 (1997). Recommended Internacional Code of Practice General Principles of Food Hygiene.

3.10. ESTADOS UNIDOS DA AMÉRICA. Code of Federal Regulations, Vol. 2, Título 9, Capítulo III, Parte 416. Sanitation.

\section{REQUISITOS PARA ELABORAÇÃO DOS PROCEDIMENTOS OPERACIONAIS} PADRONIZADOS 


\subsection{Requisitos Gerais}

4.1.1. Os estabelecimentos produtores/industrializadores de alimentos devem desenvolver, implementar e manter para cada item relacionado abaixo, Procedimentos Operacionais Padronizados - POPs.

a) Higienização das instalações, equipamentos, móveis e utensílios.

b) Controle da potabilidade da água.

c) Higiene e saúde dos manipuladores.

d) Manejo dos resíduos.

e) Manutenção preventiva e calibração de equipamentos.

f) Controle integrado de vetores e pragas urbanas.

g) Seleção das matérias-primas, ingredientes e embalagens.

h) Programa de recolhimento de alimentos.

4.1.2. Os POPs devem ser aprovados, datados e assinados pelo responsável técnico, responsável pela operação, responsável legal e ou proprietário do estabelecimento, firmando o compromisso de implementação, monitoramento, avaliação, registro e manutenção dos mesmos.

4.1.3. A freqüência das operações e nome, cargo e ou função dos responsáveis por sua execução devem estar especificados em cada POP.

4.1.4. Os funcionários devem estar devidamente capacitados para execução dos POPs.

4.1.5. Quando aplicável, os POPs devem relacionar os materiais necessários para a realização das operações assim como os Equipamentos de Proteção Individual.

4.1.6. Os POPs devem estar acessíveis aos responsáveis pela execução das operações e às autoridades sanitárias.

4.1.7. Os POPs podem ser apresentados como anexo do Manual de Boas Práticas de Fabricação do estabelecimento.

\subsection{Requisitos específicos}

4.2.1. Os POPs referentes às operações de higienização de instalações, equipamentos, móveis e utensílios devem conter informações sobre: natureza da superfície a ser higienizada, método de higienização, princípio ativo selecionado e sua concentração, tempo de contato dos agentes químicos e ou físicos utilizados na operação de higienização, temperatura e outras informações que se fizerem necessárias. Quando aplicável o desmonte dos equipamentos, os POPs devem contemplar esta operação.

4.2.2. Os Procedimentos Operacionais Padronizados devem abordar as operações relativas ao controle da potabilidade da água, incluindo as etapas em que a mesma é crítica para o processo produtivo, especificando os locais de coleta das amostras, a freqüência de sua execução, as determinações analíticas, a metodologia aplicada e os responsáveis. Quando a higienização do reservatório for realizada pelo próprio estabelecimento, os procedimentos devem contemplar os tópicos especificados no item 4.2.1. Nos casos em que as determinações analíticas e ou a higienização do reservatório forem realizadas por empresas terceirizadas, o estabelecimento deve apresentar, para o primeiro caso, o laudo de análise e, para o segundo, o certificado de execução do serviço contendo todas as informações constantes no item 4.2.1. 
4.2.3. As etapas, a freqüência e os princípios ativos usados para a lavagem e anti-sepsia das mãos dos manipuladores devem estar documentados em procedimentos operacionais, assim como as medidas adotadas nos casos em que os manipuladores apresentem lesão nas mãos, sintomas de enfermidade ou suspeita de problema de saúde que possa comprometer a segurança do alimento. Deve-se especificar os exames aos quais os manipuladores de alimentos são submetidos, bem como a periodicidade de sua execução. O programa de capacitação dos manipuladores em higiene deve ser descrito, sendo determinada a carga horária, o conteúdo programático e a freqüência de sua realização, mantendo-se em arquivo os registros da participação nominal dos funcionários.

4.2.4. Os Procedimentos Operacionais Padronizados devem estabelecer a freqüência e o responsável pelo manejo dos resíduos. Da mesma forma, os procedimentos de higienização dos coletores de resíduos e da área de armazenamento devem ser discriminados atendendo, no mínimo, aos tópicos especificados no item 4.2.1.

4.2.5. Os estabelecimentos devem dispor dos Procedimentos Operacionais Padronizados que especifiquem a periodicidade e responsáveis pela manutenção dos equipamentos envolvidos no processo produtivo do alimento. Esses POPs devem também contemplar a operação de higienização adotada após a manutenção dos equipamentos. Devem ser apresentados os POPs relativos à calibração dos instrumentos e equipamentos de medição ou comprovante da execução do serviço quando a calibração for realizada por empresas terceirizadas.

4.2.6. Os POPs referentes ao controle integrado de vetores e pragas urbanas devem contemplar as medidas preventivas e corretivas destinadas a impedir a atração, o abrigo, o acesso e ou a proliferação de vetores e pragas urbanas. No caso da adoção de controle químico, o estabelecimento deve apresentar comprovante de execução de serviço fornecido pela empresa especializada contratada, contendo as informações estabelecidas em legislação sanitária específica.

4.2.7. O estabelecimento deve dispor de procedimentos operacionais especificando os critérios utilizados para a seleção e recebimento da matéria-prima, embalagens e ingredientes, e, quando aplicável, o tempo de quarentena necessário. Esses procedimentos devem prever o destino dado às matérias-primas, embalagens e ingredientes reprovados no controle efetuado.

4.2.8. O programa de recolhimento de produtos deve ser documentado na forma de procedimentos operacionais, estabelecendo-se as situações de adoção do programa, os procedimentos a serem seguidos para o rápido e efetivo recolhimento do produto, a forma de segregação dos produtos recolhidos e seu destino final, além dos responsáveis pela atividade.

\section{MONITORAMENTO, AVALIAÇÃO E REGISTRO DOS PROCEDIMENTOS OPERACIONAIS PADRONIZADOS}

5.1. A implementação dos POPs deve ser monitorada periodicamente de forma a garantir a finalidade pretendida, sendo adotadas medidas corretivas em casos de desvios destes procedimentos. As ações corretivas devem contemplar o destino do produto, a restauração das condições sanitárias e a reavaliação dos Procedimentos Operacionais Padronizados.

5.2. Deve-se prever registros periódicos suficientes para documentar a execução e o monitoramento dos Procedimentos Operacionais Padronizados, bem como a adoção de medidas corretivas. Esses registros consistem de anotação em planilhas e ou documentos e devem ser datados, assinados pelo responsável pela execução da operação e mantidos por um período superior ao tempo de vida de prateleira do produto. 
5.3. Deve-se avaliar, regularmente, a efetividade dos POPs implementados pelo estabelecimento e, de acordo com os resultados, deve-se fazer os ajustes necessários.

5.4. Os Procedimentos Operacionais Padronizados devem ser revistos em caso de modificação que implique em alterações nas operações documentadas.

\section{ANEXO II}

LISTA DE VERIFICAÇÃO DAS BOAS PRÁTICAS DE FABRICAÇÃO EM ESTABELECIMENTOS PRODUTORES/INDUSTRIALIZADORES DE ALIMENTOS

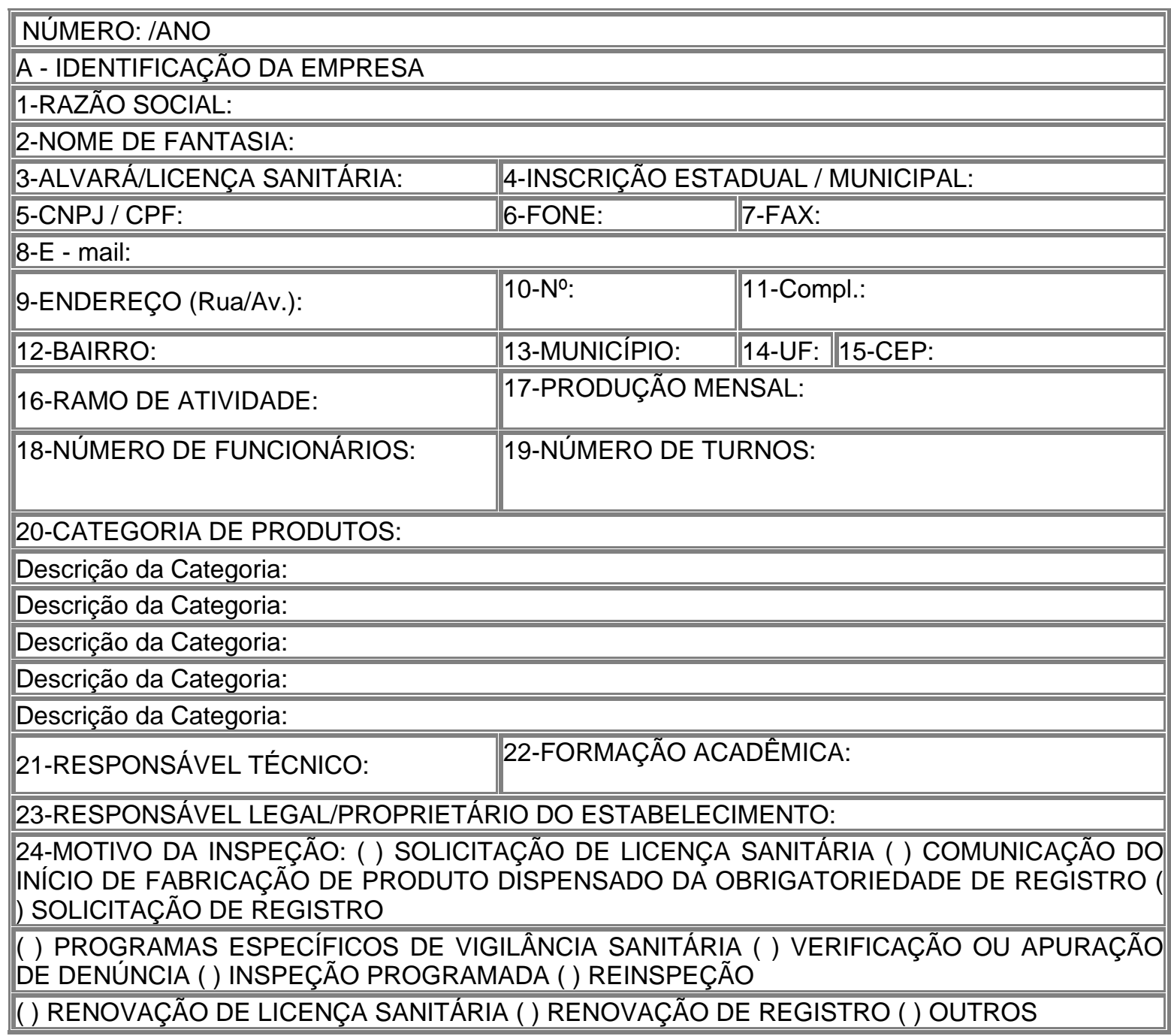

\begin{tabular}{|c|c|c|c|}
\hline \multirow{2}{*}{\multicolumn{4}{|c|}{\begin{tabular}{|l} 
B - AVALIAÇÃO \\
1. EDIFICAÇÃO E INSTALAÇÕES
\end{tabular}}} \\
\hline & & & \\
\hline 1.1 ÁREA EXTERNA: & & & \\
\hline \begin{tabular}{|l|} 
1.1.1 Área externa livre de focos de insalubridade, de objetos \\
em desuso ou estranhos ao ambiente, de vetores e outros \\
animais no pátio e vizinhança; de focos de poeira; de acúmulo \\
de lixo nas imediações, de água estagnada, dentre outros.
\end{tabular} & & & \\
\hline 1.1.2 Vias de acesso interno com superfície dura ou & & & \\
\hline
\end{tabular}




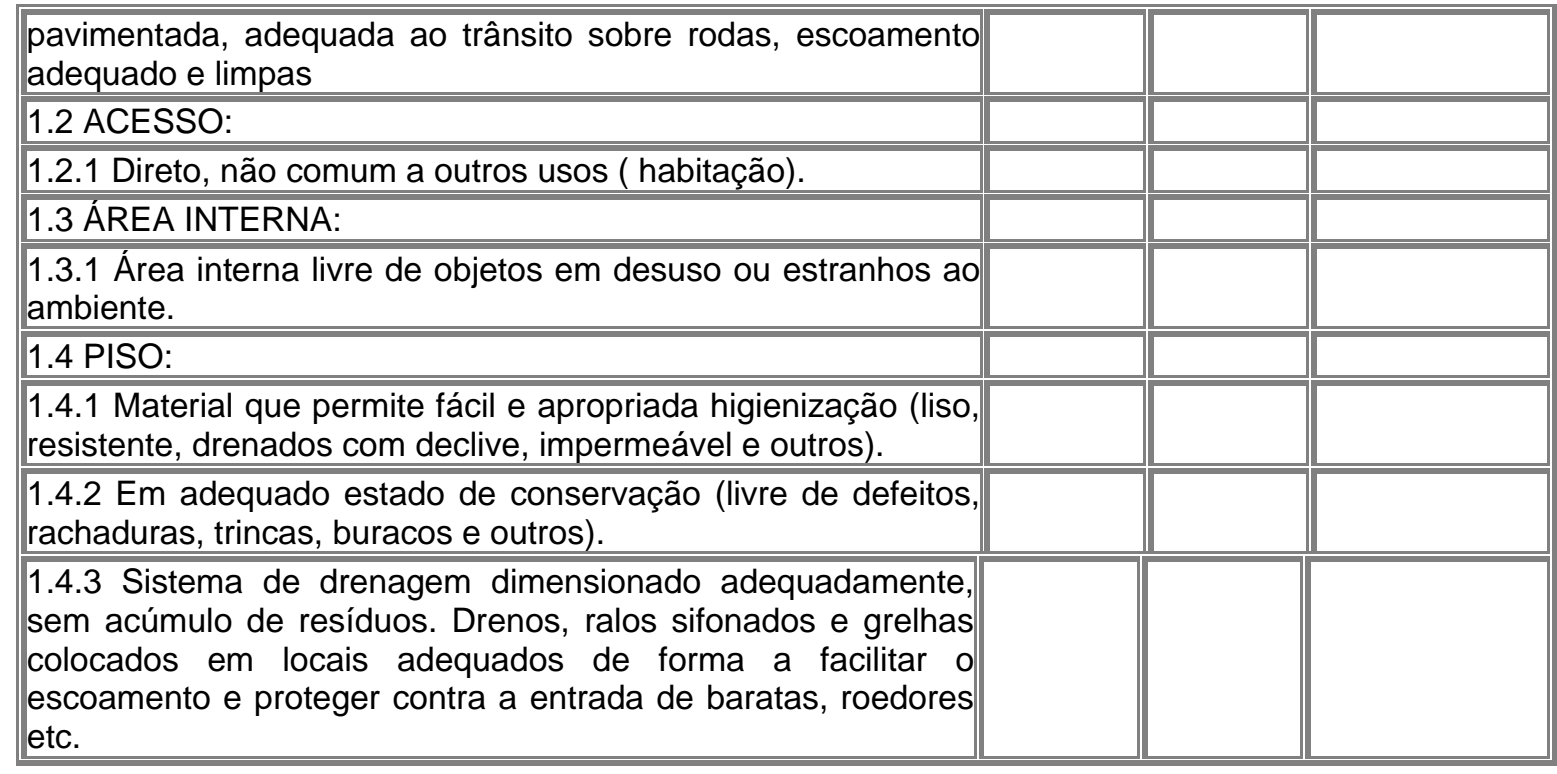

\begin{tabular}{|c|c|c|c|}
\hline B - AVALIAÇÃO & SIM & NÃO & $\mathrm{NA}(*)$ \\
\hline \multicolumn{4}{|l|}{ 1.5 TETOS: } \\
\hline \multicolumn{4}{|l|}{$\begin{array}{l}\text { 1.5.1 Acabamento liso, em cor clara, impermeável, de } \\
\text { fácil limpeza e, quando for o caso, desinfecção. }\end{array}$} \\
\hline \multicolumn{4}{|l|}{$\begin{array}{l}\text { 1.5.2 Em adequado estado de conservação (livre de } \\
\text { trincas, rachaduras, umidade, bolor, descascamentos e } \\
\text { outros). }\end{array}$} \\
\hline \multicolumn{4}{|l|}{ 1.6 PAREDES E DIVISÓRIAS: } \\
\hline \multicolumn{4}{|l|}{$\begin{array}{l}\text { 1.6.1 Acabamento liso, impermeável e de fácil } \\
\text { higienização até uma altura adequada para todas as } \\
\text { operações. De cor clara. }\end{array}$} \\
\hline \multicolumn{4}{|l|}{$\begin{array}{l}1.6 .2 \mathrm{Em} \text { adequado estado de conservação (livres de } \\
\text { falhas, rachaduras, umidade, descascamento e } \\
\text { outros). }\end{array}$} \\
\hline \multicolumn{4}{|l|}{$\begin{array}{|ll|}1.6 .3 \text { Existência de ângulos abaulados entre as } \\
\text { paredes e o piso e entre as paredes e o teto. }\end{array}$} \\
\hline \multicolumn{4}{|l|}{ 1.7 PORTAS: } \\
\hline \multicolumn{4}{|l|}{\begin{tabular}{|l} 
1.7.1 Com superfície lisa, de fácil higienização, \\
ajustadas aos batentes, sem falhas de revestimento.
\end{tabular}} \\
\hline \multicolumn{4}{|l|}{$\begin{array}{l}\text { 1.7.2 Portas externas com fechamento automático } \\
\text { (mola, sistema eletrônico ou outro) e com barreiras } \\
\text { adequadas para impedir entrada de vetores e outros } \\
\text { animais (telas milimétricas ou outro sistema). }\end{array}$} \\
\hline \multicolumn{4}{|l|}{$\begin{array}{l}\text { 1.7.3 Em adequado estado de conservação (livres de } \\
\text { falhas, rachaduras, umidade, descascamento e } \\
\text { outros). }\end{array}$} \\
\hline \multicolumn{4}{|l|}{ 1.8 JANELAS E OUTRAS ABERTURAS: } \\
\hline \multicolumn{4}{|l|}{$\begin{array}{l}\text { 1.8.1 Com superfície lisa, de fácil higienização, } \\
\text { ajustadas aos batentes, sem falhas de revestimento. }\end{array}$} \\
\hline $\begin{array}{l}\text { 1.8.2 Existência de proteção contra insetos e roedores } \\
\text { (telas milimétricas ou outro sistema). }\end{array}$ & & & \\
\hline
\end{tabular}




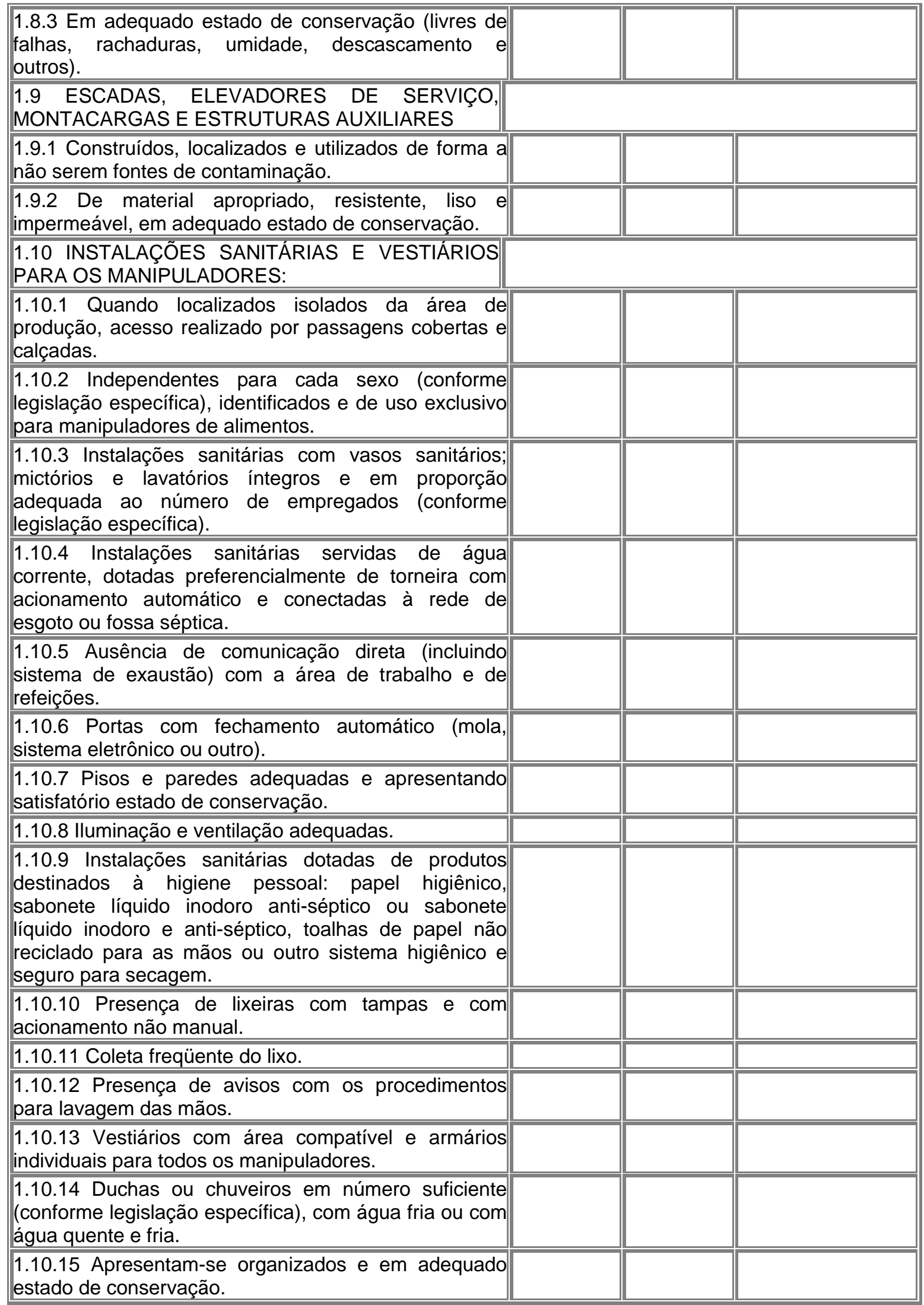




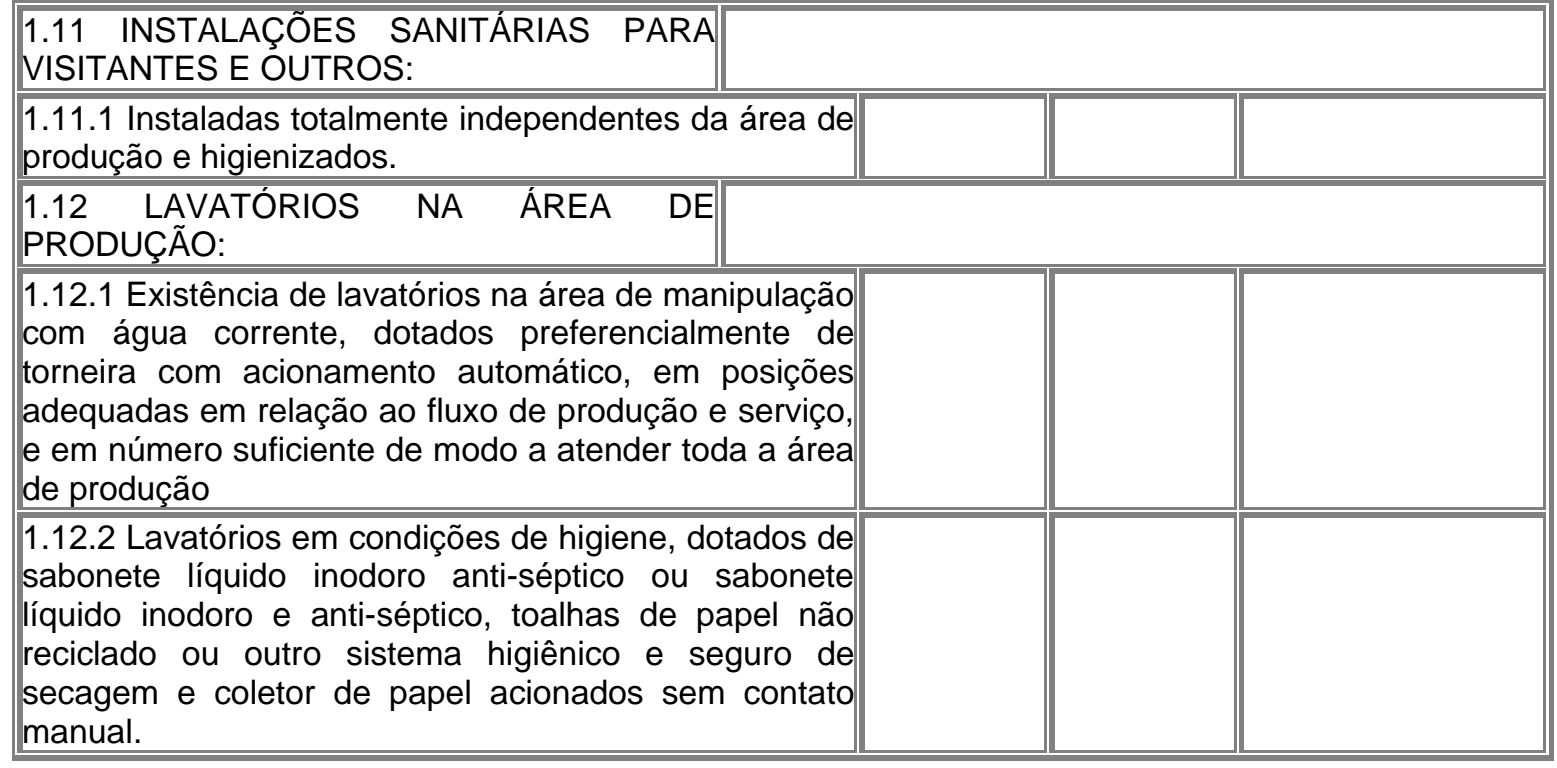

\begin{tabular}{|c|c|c|c|}
\hline B - AVALIAÇÃO & SIM & NÃO & $\mathrm{NA}\left({ }^{*}\right)$ \\
\hline \multicolumn{4}{|l|}{ 1.13 ILUMINAÇÃO E INSTALAÇÃO ELÉTRICA: } \\
\hline \multicolumn{4}{|l|}{$\begin{array}{l}1.13 .1 \text { Natural ou artificial adequada à atividade } \\
\text { desenvolvida, sem ofuscamento, reflexos fortes, } \\
\text { sombras e contrastes excessivos. }\end{array}$} \\
\hline \multicolumn{4}{|l|}{\begin{tabular}{|l||}
1.13 .2 Luminárias com proteção adequada contra \\
quebras e em adequado estado de conservação.
\end{tabular}} \\
\hline \multicolumn{4}{|l|}{$\begin{array}{l}\text { 1.13.3 Instalações elétricas embutidas ou quando } \\
\text { exteriores revestidas por tubulações isolantes e presas } \\
\text { a paredes e tetos. }\end{array}$} \\
\hline \multicolumn{4}{|l|}{ 1.14 VENTILAÇÃO E CLIMATIZAÇÃO: } \\
\hline \multicolumn{4}{|l|}{$\begin{array}{l}\text { 1.14.1 Ventilação e circulação de ar capazes de garantir } \\
\text { o conforto térmico e o ambiente livre de fungos, gases, } \\
\text { fumaça, pós, partículas em suspensão e condensação } \\
\text { de vapores sem causar danos à produção. }\end{array}$} \\
\hline \multicolumn{4}{|l|}{$\begin{array}{l}\text { 1.14.2 Ventilação artificial por meio de equipamento(s) } \\
\text { higienizado(s) e com manutenção adequada ao tipo de } \\
\text { equipamento. }\end{array}$} \\
\hline \multicolumn{4}{|l|}{$\begin{array}{l}\text { 1.14.3 Ambientes climatizados artificialmente com filtros } \\
\text { adequados. }\end{array}$} \\
\hline \multicolumn{4}{|l|}{$\begin{array}{|lllll|}1.14 .4 \text { Existência } & \text { de registro periódico } & \text { dos } \\
\text { procedimentos de limpeza e manutenção dos } \\
\text { componentes do sistema de climatização (conforme } \\
\text { legislação específica) afixado em local visível. }\end{array}$} \\
\hline \multicolumn{4}{|l|}{$\begin{array}{l}\text { 1.14.5 Sistema de exaustão e ou insuflamento com || } \\
\text { troca de ar capaz de prevenir contaminações. }\end{array}$} \\
\hline \multicolumn{4}{|l|}{$\begin{array}{l}\text { 1.14.6 Sistema de exaustão e ou insuflamento dotados } \\
\text { de filtros adequados. }\end{array}$} \\
\hline $\begin{array}{l}\text { 1.14.7 Captação e direção da corrente de ar não } \\
\text { seguem a direção da área contaminada para área } \\
\text { limpa. }\end{array}$ & & & \\
\hline
\end{tabular}




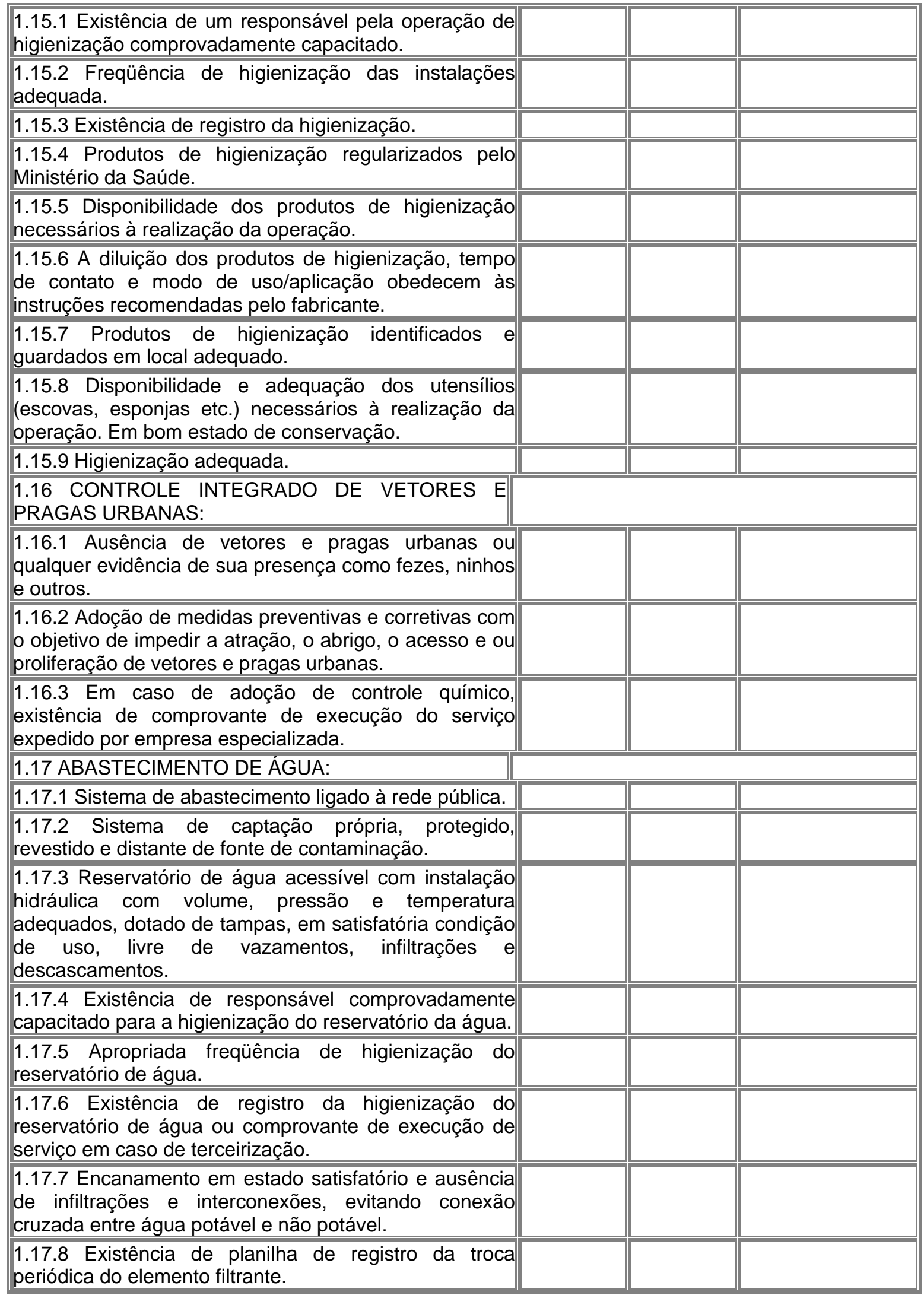




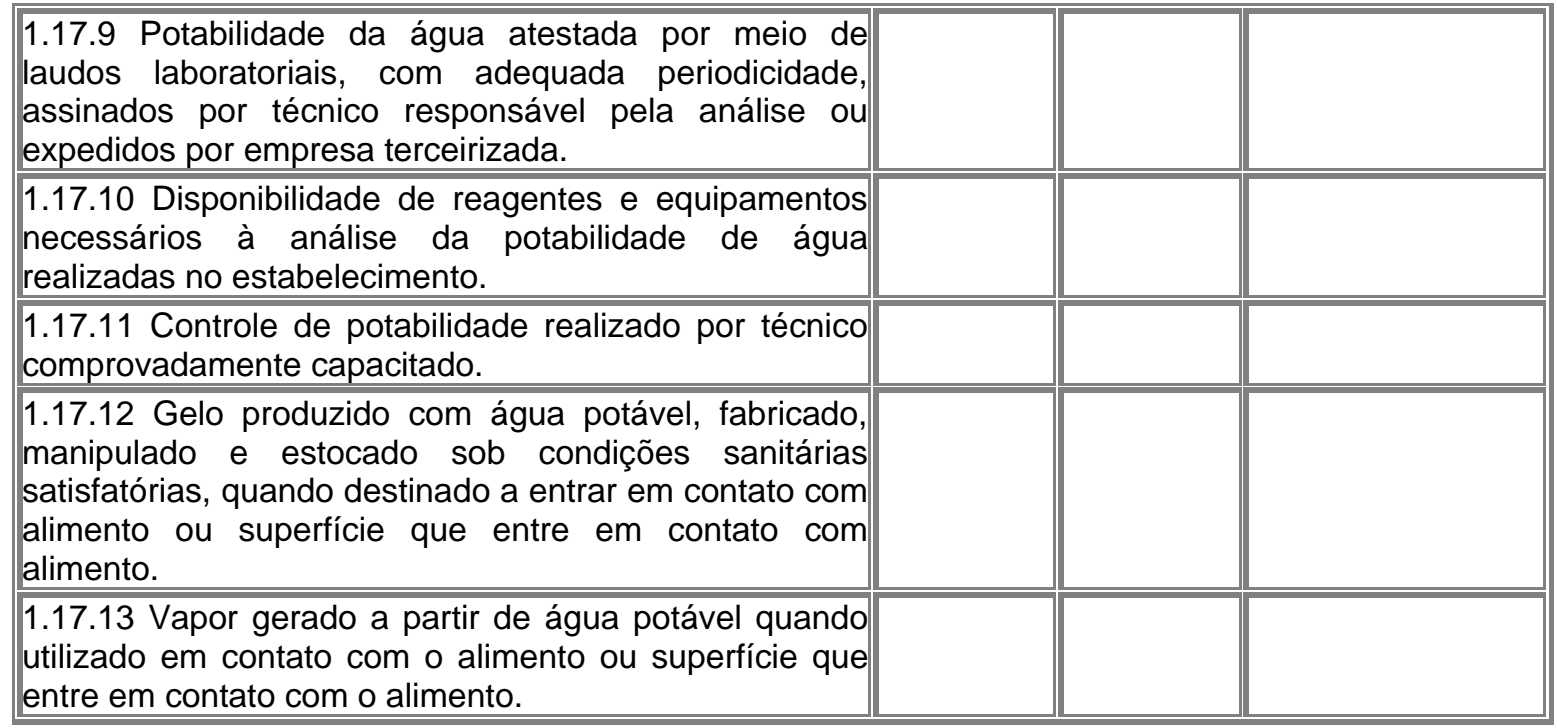

\begin{tabular}{|c|c|c|}
\hline B - AVALIAÇÃO & NÃO & $\mathrm{NA}\left({ }^{*}\right)$ \\
\hline \multicolumn{3}{|l|}{ 1.18 MANEJO DOS RESÍDUOS: } \\
\hline \multicolumn{3}{|l|}{$\begin{array}{l}\text { 1.18.1 Recipientes para coleta de resíduos no interior do } \\
\text { estabelecimento de fácil higienização e transporte, } \\
\text { devidamente identificados e higienizados } \\
\text { constantemente; uso de sacos de lixo apropriados. } \\
\text { Quando necessário, recipientes tampados com } \\
\text { acionamento não manual. }\end{array}$} \\
\hline \multicolumn{3}{|l|}{$\begin{array}{l}\text { 1.18.2 Retirada freqüente dos resíduos da área de } \\
\text { processamento, evitando focos de contaminaçãa. }\end{array}$} \\
\hline \multicolumn{3}{|l|}{$\begin{array}{l}\text { 1.18.3 Existência de área adequada para estocagem } \\
\text { dos resíduos. }\end{array}$} \\
\hline \multicolumn{3}{|l|}{ 1.19 ESGOTAMENTO SANITÁRIO: } \\
\hline \multicolumn{3}{|l|}{$\begin{array}{l}\text { 1.19.1 Fossas, esgoto conectado à rede pública, caixas } \\
\text { de gordura em adequado estado de conservação e } \\
\text { funcionamento. }\end{array}$} \\
\hline \multicolumn{3}{|l|}{ 1.20 LEIAUTE: } \\
\hline \multicolumn{3}{|l|}{$\begin{array}{l}\text { 1.20.1 Leiaute adequado ao processo produtivo: } \\
\text { número, capacidade e distribuição das dependências de } \\
\text { acordo com o ramo de atividade, volume de produção e } \\
\text { expedição. }\end{array}$} \\
\hline \begin{tabular}{|l|}
1.20 .2 Áreas para recepção e depósito de matéria- \\
prima, ingredientes e embalagens distintas das áreas de \\
produção, armazenamento e expedição de produto final.
\end{tabular} & & \\
\hline
\end{tabular}

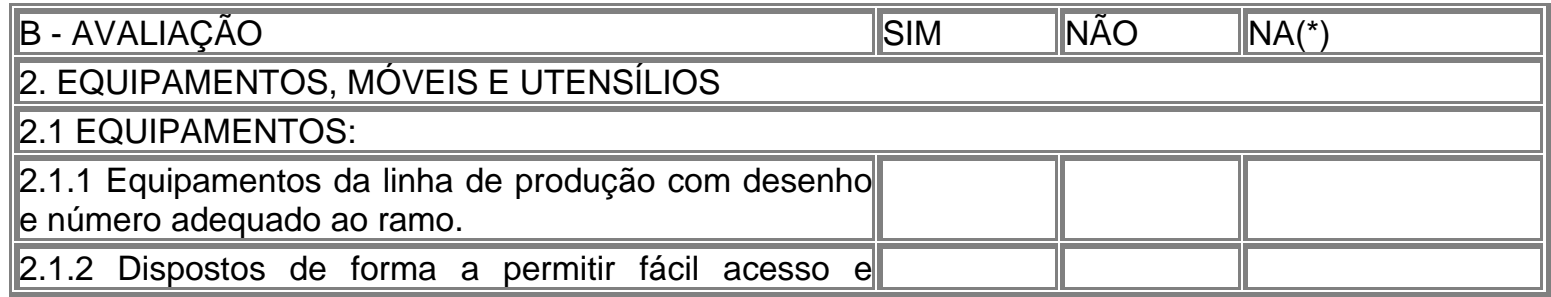




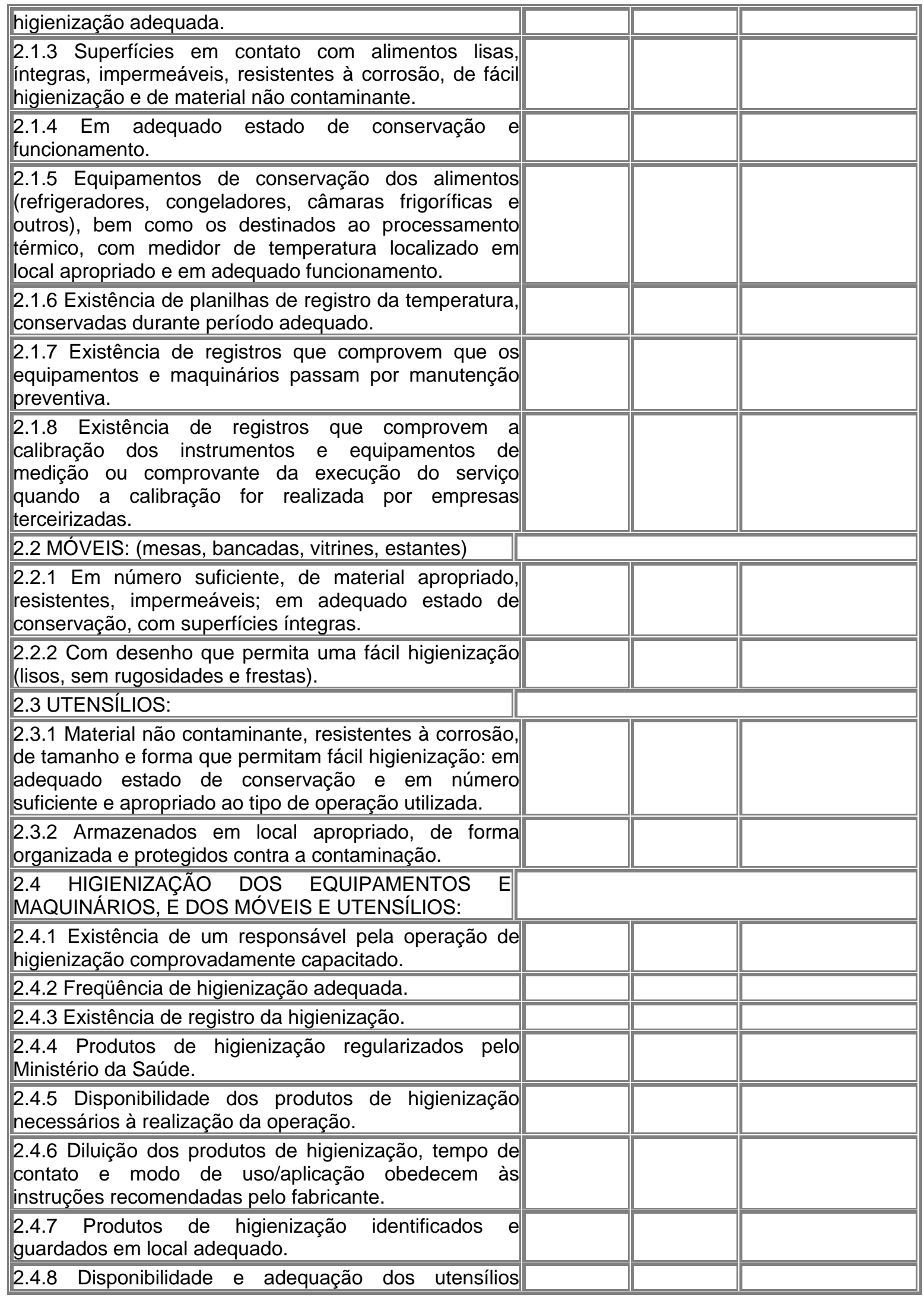




\begin{tabular}{|c|c|c|c|}
\hline $\begin{array}{l}\text { necessários à realização da operação. Em bom estado } \\
\text { de conservação. }\end{array}$ & & & \\
\hline 2.4.9 Adequada higienização. & & & \\
\hline OBSERVAÇÕES & & & \\
\hline B - AVALIAÇÃO & SIM & NÃO & $\mathrm{NA}\left(^{*}\right)$ \\
\hline 3. MANIPULADORES & & & \\
\hline 3.1 VESTUÁRIO: & & & \\
\hline $\begin{array}{l}\text { 3.1.1 Utilização de uniforme de trabalho de cor clara, } \\
\text { adequado à atividade e exclusivo para área de } \\
\text { produção. }\end{array}$ & & & \\
\hline 3.1.2 Limpos e em adequado estado de conservação. & & & \\
\hline $\begin{array}{l}\text { 3.1.3 Asseio pessoal: boa apresentação, asseio } \\
\text { corporal, mãos limpas, unhas curtas, sem esmalte, sem } \\
\text { adornos (anéis, pulseiras, brincos, etc.); manipuladores } \\
\text { barbeados, com os cabelos protegidos. }\end{array}$ & & & \\
\hline 3.2 HÁBITOS HIGIÊNICOS: & & & \\
\hline $\begin{array}{l}\text { 3.2.1 Lavagem cuidadosa das mãos antes da } \\
\text { manipulação de alimentos, principalmente após } \\
\text { qualquer interrupção e depois do uso de sanitários. }\end{array}$ & & & \\
\hline $\begin{array}{l}\text { 3.2.2 Manipuladores não espirram sobre os alimentos, } \\
\text { não cospem, não tossem, não fumam, não manipulam } \\
\text { dinheiro ou não praticam outros atos que possam } \\
\text { contaminar o alimento. }\end{array}$ & & & \\
\hline $\begin{array}{l}\text { 3.2.3 Cartazes de orientação aos manipuladores sobre a } \\
\text { correta lavagem das mãos e demais hábitos de higiene, } \\
\text { afixados em locais apropriados. }\end{array}$ & & & \\
\hline 3.3 ESTADO DE SAÚDE: & & & \\
\hline $\begin{array}{l}\text { 3.3.1 Ausência de afecções cutâneas, feridas e } \\
\text { supurações; ausência de sintomas e infecções } \\
\text { respiratórias, gastrointestinais e oculares. }\end{array}$ & & & \\
\hline 3.4 PROGRAMA DE CONTROLE DE SAÚDE: & & & \\
\hline $\begin{array}{l}\text { 3.4.1 Existência de supervisão periódica do estado de } \\
\text { saúde dos manipuladores. }\end{array}$ & & & \\
\hline 3.4.2 Existência de registro dos exames realizados. & & & \\
\hline 3.5 EQUIPAMENTO DE PROTEÇÃO INDIVIDUAL: & & & \\
\hline 3.5.1 Utilização de Equipamento de Proteção Individual. & & & \\
\hline $\begin{array}{l}\text { 3.6 PROGRAMA DE CAPACITAÇÃO DOS } \\
\text { MANIPULADORES E SUPERVISÃO: }\end{array}$ & & & \\
\hline $\begin{array}{l}\text { 3.6.1 Existência de programa de capacitação adequado } \\
\text { e contínuo relacionado à higiene pessoal e à } \\
\text { manipulação dos alimentos. }\end{array}$ & & & \\
\hline 3.6.2 Existência de registros dessas capacitações. & & & \\
\hline $\begin{array}{l}\text { 3.6.3 Existência de supervisão da higiene pessoal e } \\
\text { manipulação dos alimentos. }\end{array}$ & & & \\
\hline $\begin{array}{l}\text { 3.6.4 Existência de supervisor comprovadamente } \\
\text { capacitado. }\end{array}$ & & & \\
\hline OBSERVAÇÕES & & & \\
\hline
\end{tabular}




\begin{tabular}{|c|c|c|c|}
\hline B - AVALIAÇÃO & SIM & NÃO & $\mathrm{NA}\left({ }^{*}\right)$ \\
\hline \multicolumn{4}{|l|}{ 4. PRODUÇÃO E TRANSPORTE DO ALIMENTO } \\
\hline \multicolumn{4}{|l|}{ 4.1 MATÉRIA-PRIMA, INGREDIENTES E EMBALAGENS: } \\
\hline \multicolumn{4}{|l|}{$\begin{array}{l}\text { 4.1.1 Operações de recepção da matéria-prima, } \\
\text { ingredientes e embalagens são realizadas em local } \\
\text { protegido e isolado da área de processamento. }\end{array}$} \\
\hline \multicolumn{4}{|l|}{$\begin{array}{l}\text { 4.1.2 Matérias - primas, ingredientes e embalagens } \\
\text { inspecionados na recepção. }\end{array}$} \\
\hline \multicolumn{4}{|l|}{$\begin{array}{l}\text { 4.1.3 Existência de planilhas de controle na recepção } \\
\text { (temperatura e características sensoriais, condições de } \\
\text { transporte e outros). }\end{array}$} \\
\hline \multicolumn{4}{|l|}{$\begin{array}{l}\text { 4.1.4 Matérias-primas e ingredientes aguardando } \\
\text { liberação e aqueles aprovados estão devidamente } \\
\text { identificados. }\end{array}$} \\
\hline \multicolumn{4}{|l|}{$\begin{array}{l}\text { 4.1.5 Matérias-primas, ingredientes e embalagens } \\
\text { reprovados no controle efetuado na recepção são } \\
\text { devolvidos imediatamente ou identificados e } \\
\text { armazenados em local separado. }\end{array}$} \\
\hline \multicolumn{4}{|l|}{$\begin{array}{l}\text { 4.1.6 Rótulos da matéria-prima e ingredientes atendem } \\
\text { à legislação. }\end{array}$} \\
\hline \multicolumn{4}{|l|}{$\begin{array}{l}\text { 4.1.7 Critérios estabelecidos para a seleção das } \\
\text { matérias-primas são baseados na segurança do } \\
\text { alimento. }\end{array}$} \\
\hline \multicolumn{4}{|l|}{$\begin{array}{l}\text { 4.1.8 Armazenamento em local adequado e organizado; } \\
\text { sobre estrados distantes do piso, ou sobre paletes, bem } \\
\text { conservados e limpos, ou sobre outro sistema aprovado, } \\
\text { afastados das paredes e distantes do teto de forma que } \\
\text { permita apropriada higienização, iluminação e circulação } \\
\text { de ar. }\end{array}$} \\
\hline \multicolumn{4}{|l|}{$\begin{array}{l}\text { 4.1.9 Uso das matérias-primas, ingredientes e } \\
\text { embalagens respeita a ordem de entrada dos mesmos, } \\
\text { sendo observado o prazo de validade. }\end{array}$} \\
\hline \multicolumn{4}{|l|}{$\begin{array}{l}\text { 4.1.10 Acondicionamento adequado das embalagens a } \\
\text { serem utilizadas. }\end{array}$} \\
\hline \multicolumn{4}{|l|}{$\begin{array}{l}\text { 4.1.11 Rede de frio adequada ao volume e aos } \\
\text { diferentes tipos de matérias-primas e ingredientes. }\end{array}$} \\
\hline \multicolumn{4}{|l|}{ 4.2 FLUXO DE PRODUÇÃO: } \\
\hline \multicolumn{4}{|l|}{$\begin{array}{l}\text { 4.2.1 Locais para pré - preparo ("área suja") isolados da } \\
\text { área de preparo por barreira física ou técnica. }\end{array}$} \\
\hline \multicolumn{4}{|l|}{ 4.2.2 Controle da circulação e acesso do pessoal. } \\
\hline \multicolumn{4}{|l|}{$\begin{array}{l}\text { 4.2.3 Conservação adequada de materiais destinados } \\
\text { ao reprocessamento. }\end{array}$} \\
\hline \multicolumn{4}{|l|}{ 4.2.4 Ordenado, linear e sem cruzamento. } \\
\hline B - AVALIAÇÃO & SIM & NÃO & $\mathrm{NA}\left({ }^{*}\right)$ \\
\hline \multicolumn{4}{|l|}{ 4.3 ROTULAGEM E ARMAZENAMENTO DO PRODUTO-FINAL: } \\
\hline \multicolumn{4}{|l|}{$\begin{array}{l}\text { 4.3.1 Dizeres de rotulagem com identificação visível e de } \\
\text { acordo com a legislação vigente. }\end{array}$} \\
\hline $\begin{array}{l}\text { 4.3.2 Produto final acondicionado em embalagens } \\
\text { adequadas e íntegras. }\end{array}$ & & & \\
\hline
\end{tabular}




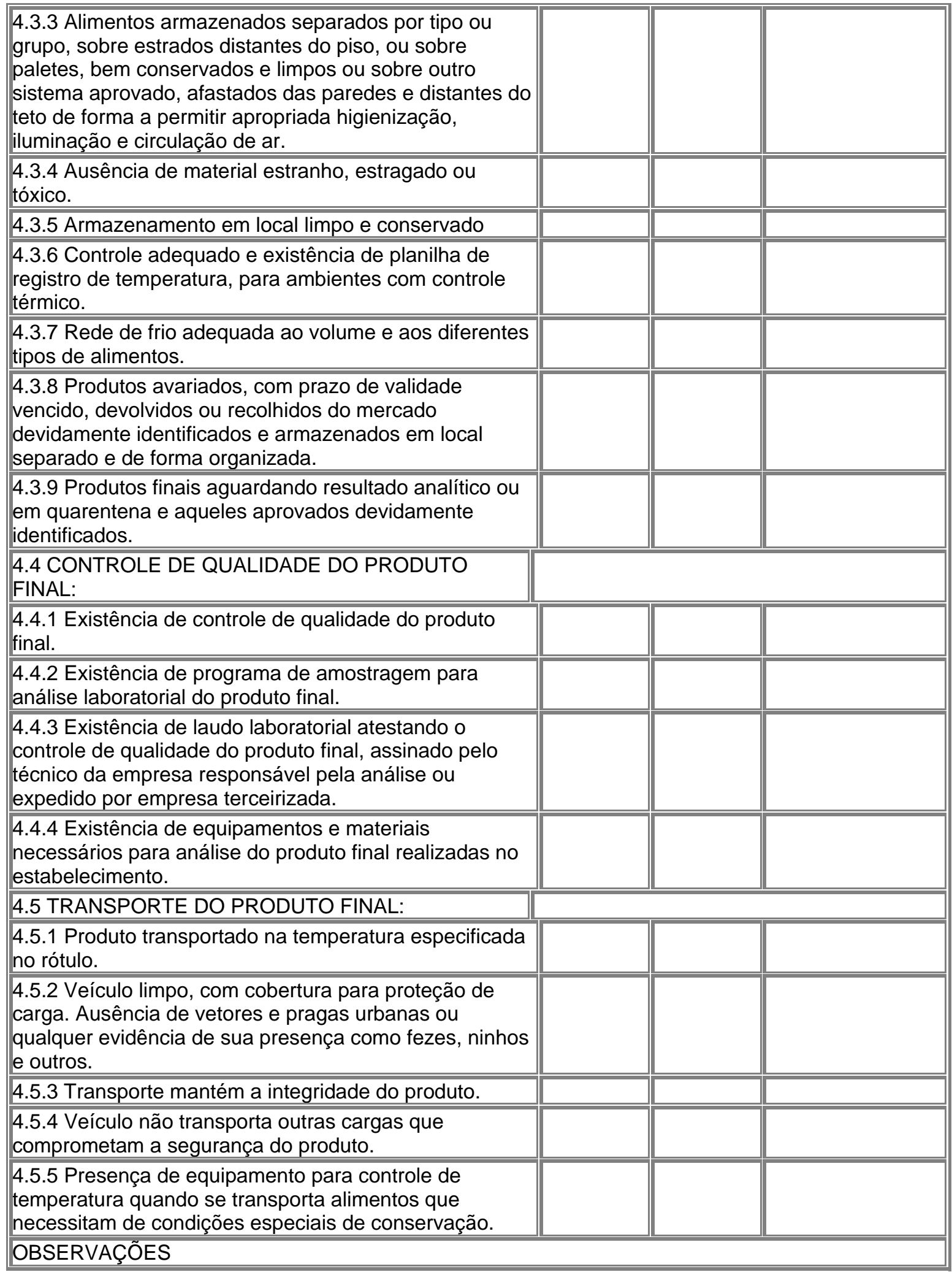

\begin{tabular}{|l||l||l||l||}
\hline$B$ - AVALIAÇÃO & SIM & NÃO & NA(*) \\
\hline
\end{tabular}




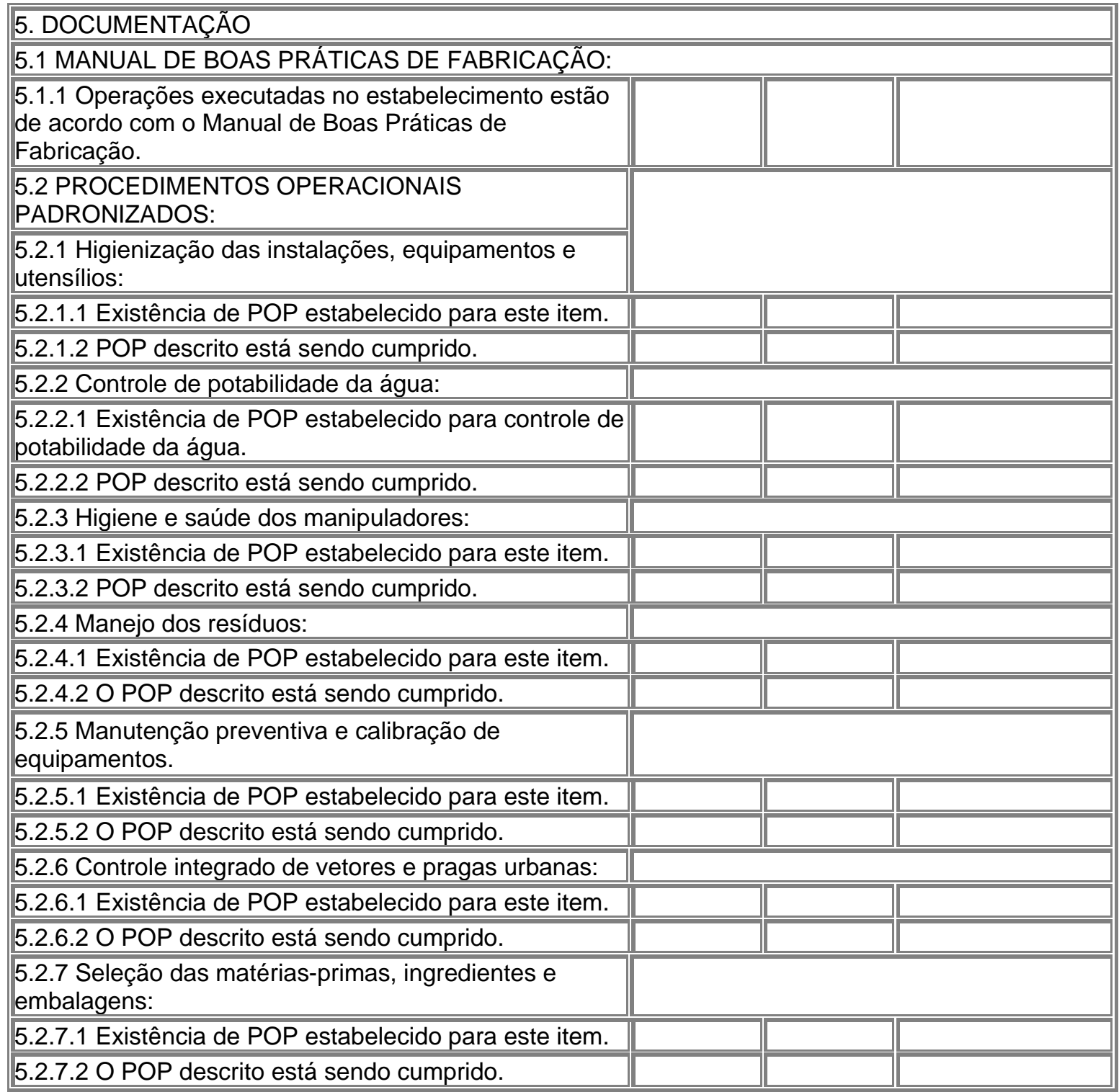

\begin{tabular}{|c|c|c|c|}
\hline$B$ - AVALIAÇÃO & SIM & NÃO & NA $\left({ }^{*}\right)$ \\
\hline 5.2.8 Programa de recolhimento de alimentos & & & \\
\hline 5.2.8.1 Existência de POP estabelecido para & & & \\
\hline 5.2.8.2 O POP descrito está sendo cumprido. & & & \\
\hline OBSERVAÇÕES & & & \\
\hline
\end{tabular}

\section{C - CONSIDERAÇÕES FINAIS}

\section{D - CLASSIFICAÇÃO DO ESTABELECIMENTO}

Compete aos órgãos de vigilância sanitária estaduais e distrital, em articulação com o órgão competente no âmbito federal, a construção do panorama sanitário dos estabelecimentos produtores/industrializadores de alimentos, mediante sistematização dos dados obtidos nesse item. 
O panorama sanitário será utilizado como critério para definição e priorização das estratégias institucionais de intervenção.

( ) GRUPO 1 - 76 A 100\% de atendimento dos itens ( ) GRUPO 2 - 51 A 75\% de atendimento dos itens () GRUPO 3 - 0 A 50\% de atendimento dos itens

\begin{tabular}{|c|c|}
\hline E - RESPONSÁVEIS PELA INSPEÇÃO & \\
\hline assinatura do responsável Matrícula: & $\mid \begin{array}{l}\text { Nome e } \\
\text { assinatura do responsável Matrícula: }\end{array}$ \\
\hline
\end{tabular}

\section{F - RESPONSÁVEL PELA EMPRESA} Nome e assinatura do responsável pelo

estabelecimento

\begin{tabular}{|l||l|l|}
\hline LOCAL: & DATA: & $l$ \\
\hline
\end{tabular}

(*) NA: Não se aplica

Republicada por ter saído com incorreção, do original, no D.O.U. n $\mathbf{2 0 6}$, de 23-10-2002, Seção 1, pág. 126. 